\title{
Chief Executive Officer Incentives, Monitoring, and Corporate Risk Management: Evidence from Insurance Use
}

\author{
Mike Adams \\ Bath University, UK \\ Email: mba25@management.bath.ac.uk \\ Telephone: +44 (0) 1225385685 \\ Chen Lin \\ Chinese University of Hong Kong \\ Email: chenlin@baf.msmail.cuhk.edu.hk \\ Telephone: +852 26098566 \\ Hong Zou* \\ City University of Hong Kong \\ Email: hongzou@cityu.edu.hk \\ Telephone: +85234427880
}

\begin{abstract}
Corporate governance and risk management issues have received prominent publicity in recent years following several major company failures such as Bear Stearns and Lehman Brothers. While prior studies have examined this issue within the context of derivatives' trading, little is known regarding the linkage between corporate governance and alternative corporate risk management activities such as insurance. Using a detailed firm survey conducted by the World Bank (2004), we examine the impacts of various governance monitoring mechanisms and $\mathrm{CEO}$ characteristics on the corporate insurance decision. Overall, our results suggest that both monitoring mechanisms and managerial incentives induce the corporate purchase of property insurance. However, the purchase of property insurance for managerial self-interest is only prevalent in firms subject to lax monitoring and the determinants of insurance purchases are more in line with the prediction of the economic theory in firms with strong monitoring. In addition, our study contributes a number of new insights into the determinants of corporate purchase of property insurance.
\end{abstract}

JEL classification: G22, G30, G32

Keywords: Corporate Risk Management; Insurance; Corporate Governance; Managerial Incentives; Monitoring; China.

* corresponding author. We thank the valuable comments of George Dionne (the editor) and two anonymous reviewers that help improve the article. The usual disclaimer applies. 


\section{Chief Executive Officer Incentives, Monitoring and Corporate Risk Management: Evidence from Insurance Use}

\section{Introduction}

This study investigates the linkage between Chief Executive Officer (CEO) incentives and the monitoring of managerial behaviors and corporate risk management via insurance use. Our research has two objectives. First, we examine whether various forms of managerial compensation, CEO characteristics, and governance monitoring mechanisms affect corporate insurance decisions. Second, we investigate whether firms subject to different levels of monitoring purchase insurance for different reasons.

Asking these questions is germane given that recent company failures such as Bear Stearns, Lehman Brothers in the United States (US) and Northern Rock in the United Kingdom (UK) have heightened the importance of corporate risk management and the monitoring of such activities. Several studies (Allayannis, Lel and Miller, 2003; Borokhovich, Brunarski, Crutchley and Simkins, 2004; Dionne and Triki, 2005; Lel, 2005; Marsden and Prevost, 2005) have examined the effects of corporate governance on corporate derivatives use. ${ }^{1}$ Though enlightening, these studies tell us little about the effects of corporate governance on other means of corporate risk management such as insurance. Some published studies (e.g., Mayers and Smith, 1990; Yamori, 1999; Hoyt and Khang, 2000; Zou, Adams and Buckle, 2003; Zou and Adams, 2006; 2008; Regan and Hur, 2007; Aunon-Nerin and Ehling, 2008) have empirically examined the determinants of corporate insurance and none of them has focused on the effects of CEO incentives and corporate governance. ${ }^{2}$ Insurance, however, as a commonly used pure hedge for accidental asset-loss risks provides an interesting setting within which to examine the effects of corporate governance on corporate risk

\footnotetext{
${ }^{1}$ Borokhovich et al. (2004) find that independent directors encourage the use of interest rate derivatives for a sample of U.S. firms. Dionne and Triki (2005) analyze the effect of directors with training in accounting and directors with university education on corporate use of financial derivatives and find such directors encourage derivatives hedging. In contrast, Marsden and Prevost (2005) report that in New Zealand there was a negative relation between the proportion of independent directors on the board and the incidence of derivatives use following the passing of the 1993 Companies Act that imposes stricter fiduciary responsibilities. Using a cross-country sample, Allayannis et al. (2003) report that derivatives only increases value for investors in firms with strong corporate governance and only in countries with strong external regulation. Using the same sample, Lel (2005) finds that firms with good corporate governance are more likely to use derivatives for hedging rather than for speculation or managerial self-interest purposes.

2 These studies typically only consider the effects of the ownership of large shareholders and/or managers on the corporate purchase of insurance.
} 
management since it only deals with left-tail risks (Adams, Hardwick and Zou, 2008; Aunon-Nerin and Ehling, 2008). Mayers and Smith (1982) further argue that insurance is an integral part of corporate financial policy and so it is likely an important issue for the CEO and board members to consider.

Moreover, prior studies (e.g., Borokhovich et al., 2004; Marsden and Prevost, 2005) on corporate governance and risk management mainly focus on the role of outside independent directors on the derivatives use and have reported mixed evidence. It is not clear whether the mixed findings regarding the effects of board independence on the corporate use of derivatives is confounded by the varying quality of derivatives reporting or results from directors' unfamiliarity with technically complicated derivatives trading. In contrast, managerial sophistication is not a prerequisite for a successful insurance strategy (Aunon-Nerin and Ehling, 2008; Zou, 2009).

Using a detailed survey of Chinese firms conducted by the World Bank, we test the impacts of various proxies for CEO incentives and several governance monitoring mechanisms on corporate purchases of property insurance in China. ${ }^{3}$ The World Bank survey dataset affords several key advantages relative to data collected from the voluntary disclosures of insurance by listed companies. First, self-selection bias is not a significant issue in our sample. Indeed, more than $99.5 \%$ of those surveyed firms reported their insurance spending (including nil spending). Second, our sample has a more balanced mix of insurance users (slightly over 50\%) and non-users compared with the listed company samples used in prior studies (e.g., Zou and Adams, 2008) (where over $90 \%$ of sample firms purchased property insurance), and this enables us to conduct a more powerful test of research hypotheses. Third, it provides detailed information on CEO characteristics and incentives (e.g., compensation and political connections) from which we are able to provide a comprehensive test of CEOs' incentives on the corporate purchase of insurance. The survey dataset also covers both listed and unlisted companies with a variety of ownership structures and includes firms with significant variations in corporate governance, and hence, it is well suited for our investigation. In contrast, listed companies in China tend to have a more homogenous corporate governance structure as a result of the regulatory requirements introduced by the China

\footnotetext{
${ }^{3}$ At the time the survey was carried out (in 2003), the majority of corporate insurance purchases was related to property insurance as other forms of indemnity cover (such as liability insurance) were relatively minor (e.g., see Zou and Adams, 2006). The corporate purchase of property insurance is also a voluntary decision in China.
} 
Securities Regulatory Commission (CSRC). There is no doubt that survey data may be subject to potential bias in data collection. However, given that the same dataset has been used in academic research (e.g., Cull and Xu, 2005), we believe the overall data quality is sufficiently good.

China is an interesting setting within which to examine the above issue for at least two reasons. First, insurance is the major commercial risk management tool in China as the market for alternative hedging techniques (e.g., financial derivatives) is currently undeveloped (Zou and Adams, 2008). This attribute enables us to avoid the potentially confounding effects of (unobserved) hedging substitutes (such as derivatives use) on our results (Petersen and Thiagarajan, 2000). Second, China has remained one of the most attractive places in the world for foreign direct and indirect investments plus there are also increasing numbers of Chinese companies that are actively seeking overseas listing status (e.g., in the US). As a result, by focusing on the interplay between corporate governance and insurance decisions in China our study is likely to be of interest to investors, financial analysts, amongst others.

The richness of different types of firms in our sample enables us to measure corporate governance in a variety of ways. Since there may not be a single model of optimal corporate governance for all companies (Coles, Daniel and Naveen, 2008), we only consider corporate governance mechanisms that concern the monitoring of CEOs and that lowers the risk of severe shareholder-manager and shareholder-debtholder incentive conflicts. ${ }^{4}$ Specifically, this is measured in terms of whether a firm is a privately-controlled or joint-stock company that is subject to annual external audit and the monitoring of foreign institutional investors, whether a firm has a board of directors with independent (outside) directors that also separates the CEO and board chairman positions, the extent to which has board members hold the firm's shares, and whether a firm deals with a bank that has a collateral requirement in offering a loan. We also examine the effects of CEO compensation and other incentive measures on property insurance decisions.

We find that both CEO personal incentives and governance monitoring mechanisms can induce

\footnotetext{
${ }^{4}$ For example, while research in corporate governance generally argues that small and more independent boards are optimal, Coles et al. (2008) show that in complex firms (characterized by large size, diversified and high leverage), firm performance increases in board size. Also, in R\&D-intensive firms for which firm-specific knowledge is more important, firm performance increases in the proportion of inside directors. Given this, instead of categorizing firms into firms with good or poor governance, our examination focuses on the effect of monitoring exerted by the board of directors and other stakeholders, and CEO incentives on corporate insurance decisions. We thank an anonymous reviewer for suggesting this.
} 
corporate insurance purchase. The statistically significant measures of CEO incentives include CEOs' cash compensation (salary and bonus) (a proxy for managerial wealth tied up in the firm), CEO tenure (a proxy for human capital invested in the firm or managerial entrenchment), whether the CEO was a manager before (a proxy for reputational capital or professionalism), whether the CEO is a secretary of the ruling Communist Party (a proxy for the CEO's political connections and career prospects), and the use of safety of operation as an evaluation criterion in managerial incentive contracts. Monitoring mechanisms that have important impacts on the incidence of property insurance include foreign institutional ownership, whether a firm's financial statements are subject to external auditing, the separation of CEO and Chairman positions, the ownership of board members. Second, we find that firms subject to different monitoring tend to purchase property insurance for different purposes. Specifically, the purchase of property insurance for managerial self interest is only prevalent in firms subject to lax monitoring and the determinants of insurance purchase are more in line with the prediction of the economic theory in firms with strong monitoring. Our study, as the first conducted in the context of insurance, adds to the emerging literature regarding the linkage between corporate governance and corporate risk management.

Third, our study contributes some new insights into the determinants of corporate insurance. For example, we provide evidence of empirical linkages between external auditing, product market competition, labor representation on the board of directors, and the corporate use of insurance, which have not been previously documented in the literature. Finally, a refined control for the location factor (by including location fixed-effects and using clustered standard errors to control for potential cross-sectional correlation) represents a methodological improvement over prior studies and enables us to derive more robust results.

The remainder of our paper is organized as follows. Section 2 introduces corporate governance in China and Section 3 motivates our hypotheses. We describe research design in Section 4. The empirical results are provided in Section 5, and Section 6 concludes the paper.

\section{Corporate Governance in China}

Corporate governance has been identified by the Chinese government as the core element of the "modern enterprise system". Over the last twenty years or so, China has made significant progress in developing the institutional foundations of a modern corporate governance system 
(Tenev and Zhang, 2002). For example, according to the Company Law (1993), Chinese firms operate a two-tier board structure - namely a board of directors and a supervisory board. ${ }^{5}$ The independent director system was mandated in 2001 by the CSRC and listed firms are required to have at least one third of their board members being independent directors (including at least one independent director with a professional accountancy background) by June 30, 2003. In addition, listed firms are also required to establish audit, nomination and remuneration committees comprising a majority of independent directors. ${ }^{6}$

Corporate governance reform in China has attracted significant research interest since it offers a unique opportunity to examine the effect of corporate governance on corporate behaviors (Liu and $\mathrm{Lu}, 2007)$. Overall, research shows that Chinese firms, as they become more and more market-oriented, have adopted corporate governance schemes that are largely consistent with those of western countries. Furthermore, in line with the organization theory and finance literature, corporate governance in China has been shown to have exerted significant impacts on firm behaviors and performance.

For instance, there is evidence that ownership structure and ownership transfer exert significant impacts on firm performance (Sun and Tong, 2003; Wei, Xie and Zhang, 2005) or market value (Chen, Firth, Xin and Xu, 2008). In addition, executive (i.e. CEO, board chairman) turnover and compensation seem to be closely related to firm performance (Aivazian, Ge and Qiu, 2005; Firth, Fung and Rui, 2006a, 2006b). Furthermore, other aspects of corporate governance such as board independence (e.g. Chen, Firth, Gao and Rui, 2006), board diligence (Lin, Ma and Su, 2008), CEO duality (Bai, Liu, Lu, Song and Zhang, 2004), political connection (Fan, Wong and Zhang, 2007; Firth, Lin, Liu and Wong, 2009) and external governance mechanisms (e.g. property rights

\footnotetext{
${ }^{5}$ Xiao, Dahya and Lin (2004) note that the supervisory board is largely symbolic and ineffectual; they thus contend that the system of corporate governance in China is essentially equivalent to the single-tier system that operates in Anglo-American countries.

${ }^{6}$ Berkman, Cole and Fu (2010) note that some governance rules and regulations in China are even stricter than those of Hong Kong stock market (e.g., in terms of quarterly reporting). While the 1993 Company Law did not establish a formal concept of fiduciary duty for directors and officers until its revision in 2005, Corporate Governance Standard for Listed Companies issued by the CSRC in 2002 imposes fiduciary duties on directors and officers and allows shareholders to bring derivatives suits against directors and officers who breached fiduciary duties. Though actual suits remain to be seen in practice, shareholders in principle may sue company directors and officers for negligence or failure in managing key risks.
} 
protection, contract enforcement) (Cull and Xu, 2005; Lin, Lin and Song, 2009) tend to affect firm performance, efficiency, corporate financing or investment.

\section{CEO Incentives, Corporate Governance and Corporate Insurance}

In this section we discuss the effects of CEO incentives and governance on the corporate purchase of property insurance. We also consider the market imperfections motives for corporate risk management.

\subsection{CEO Incentives and Corporate Insurance}

Several authors (e.g., Smith and Stulz, 1985; May, 1995; Tufano, 1996; Allayannis et al., 2003) note that corporate risk management activities may be motivated by the objective of maximizing managers' utility function, particularly when they have non-diversified financial and human capital that is tied to the firm's wealth. If so, such insurance purchase may not be value-increasing for shareholders. In the following, we discuss the effects of CEO compensation and CEO characteristics that determine CEO incentives.

\subsubsection{CEO compensation and corporate insurance}

Strictly speaking, CEO compensation is a part of the corporate governance structure. ${ }^{7}$ However, since different forms of compensation may lead to different incentives for risk-taking or risk reduction (Smith and Stulz, 1985; Saunders, Strock and Travlos, 1990; Han, 1996; Han and MacMinn, 2006), we discuss and examine their effects separately. As in our sample period, executive stock option plans did not exist in China, our following discussion focuses on the effects of managerial ownership, bonus and salary.

Managerial Ownership: There are three different views concerning the impact of managerial ownership on corporate risk management. First, the managerial incentive alignment advanced by Saunders et al. (1990) predicts that as insider ownership increases, managers' interests become more closely aligned with shareholders' interests, and as a result, managers have incentives to increase the level of business risk or engage in less risk management. Han and MacMinn (2006) also contend that if managers are compensated in stock then they are likely to engage in risk-taking behavior if such actions are expected to increase shareholder value. In the context of corporate

\footnotetext{
${ }^{7}$ In fact, Tirole (2001) defined corporate governance as the design of institutions that induce or force management to internalize the welfare of shareholders. The provision of managerial incentives is regarded as one of the most important factors to induce or force the internalization process.
} 
insurance, Hoyt and Khang (2000) find supporting evidence in the U.S. corporate sector.

Second, the managerial self interest hypothesis ${ }^{8}$, advanced by Smith and Stulz (1985), holds that managers are often unable to effectively diversify risks specific to their claims (both financial income and firm-specific human capital) on the corporation. Consequently, as the proportion of managers' shares increases, they have more incentives to pursue risk reduction strategies. Consistent with this view, May (1995) finds that in the US CEOs with more personal wealth vested in a firm's equity tend to diversify. Tufano (1996) also finds that in the U.S. gold mining industry, firms whose managers hold large numbers of ordinary shares are more likely to hedge gold price risk. From a sample of Chinese listed companies for the period 1997-1999, Zou and Adams (2006) conclude that high amounts of property insurance are associated with greater levels of managerial ownership.

A third view is that a manager compensated through shares may be indifferent to the purchase of insurance (MacMinn, 2005). On the one hand, as discussed above, managerial ownership helps align the interests of managers and shareholders, which may lead to less risk management. On the other hand, such incentive alignment also creates the debt overhang problem, which can be solved by the purchase of appropriate asset insurance cover by managers who want to maximize shareholders' wealth (see Garven and MacMinn, 1993). ${ }^{9}$ Campbell and Kracaw (1987) argue that shareholders would prefer managers to hedge or insure observable incidental risks (e.g., property/liability risks) that are beyond the control of managers because hedging may lower the risk premiums paid to risk-averse managers and induce them who are rewarded by a linear payoff (e.g., through share ownership or share ownership plus salary) to be more productive. They also show when the insurable risk is dependent on managerial effort, the incentive contract (e.g., managerial share ownership) that provides a linear payoff may lead to either over or under insurance by the

\footnotetext{
${ }^{8}$ We note that if the Fisher separation theorem holds, managerial risk aversion should not have an effect on corporate behavior (MacMinn, 2005). However, in a nascent market like China where financial markets are incomplete and subject to significant frictions, agency problems are severe and state ownership is present in many firms. In addition, Chinese managers often have non-diversified personal portfolios because they mainly derive income and other benefits from the company employing them. The lack of a nationwide developed managerial labor market also reduces company managers' mobility (Firth et al., 2006a). Therefore, managers' risk aversion and self interest may affect corporate insurance decisions in China and our study should be construed as a test of CEO incentives due to risk aversion and self interest, and the monitoring of such behavior in corporate insurance decisions in an incomplete financial market.

${ }^{9}$ We thank an anonymous referee for making this point.
} 
manager relative to that preferred by shareholders, depending on the size of their relative shareholdings in the firm. Therefore, theory does not provide a clear prediction of the effect of managerial ownership on corporate insurance.

Bonus Plan: Little attention has been paid to the risk management incentives resulting from bonus plans (Kim, Nam and Thornton, 2008, p.230). Neither there is a formal theory as to the effects of bonus plan on corporate use of insurance. One reason may be that ". . . bonuses can be and are specified in so many different ways that it is difficult to generalize" (Han and MacMinn, 2006, p. 254). Brander and Poitevin (1992) show that a bonus payment to managers that is not closely related to shareholders' wealth can be used as a commitment device by shareholders to help mitigate the agency costs of debt financing and thereby facilitate debt borrowing. Their analysis provides a basis for claiming that earnings-based bonuses may provide an incentive to insure.

If a bonus scheme just has a pre-determined earnings threshold and does not impose a ceiling on the amount of the bonus, the bonus plan mimics a call stock option and so Han and MacMinn's (2006) reasoning that stock option plans provide an incentive for managers to insure the firm's property and liability risks should apply. ${ }^{10}$ If a bonus plan also imposes a ceiling on the amount of the pay-off then the bonus plan is more than just a call option. Following the reasoning of Kim et al. (2008), when the performance measure is expected to well exceed the threshold for bonus payment, managers may have incentives to reduce firm risk to lock in the bonus and hence are better motivated to insure risks. Another way to see this is that insurance unlike derivatives hedging simply provides a protection against the downside risk, but still retains the upside potential (Han and MacMinn (2006, p.232). We therefore predict a positive effect of having a bonus plan on the corporate purchase of property insurance. ${ }^{11}$

Flat Salary: Doherty (2000) argues that when managers are rewarded with a flat-rate salary, they are unlikely to have a direct monetary interest in hedging, but they may still be motivated to

\footnotetext{
${ }^{10}$ Han and MacMinn (2006) show that insurance of pure risks reduces the weight in the left-hand tail when stock options are out-of-the-money and increases the weight in the right-hand tail when stock options are in-the-money, thereby providing managers with incentives to take out insurance.

${ }^{11}$ We do not have detailed information on bonus plans other than the existence of a bonus plan or not; neither do we know whether a firm had not a bonus plan before it has ever purchased any insurance. As a result, our attempt should not be viewed as a formal test. Nevertheless, given the paucity of empirical evidence regarding the effect of bonus plan on corporate insurance, we believe it is useful to include a bonus plan dummy in our model.
} 
engage in risk management if it enhances their job security or performance evaluation.

\subsubsection{CEO characteristics and corporate insurance}

While many studies have examined the effects of managerial compensation on corporate risk management, few have considered the effects of other CEO characteristics. One exception is May's (1995) study that examines the effect of managers' human capital tied up in the firm and managerial compensation on corporate diversification decisions. He shows that CEOs who have more years and more personal wealth vested in the firms that employ them are more likely to pursue a diversification strategy. Taking advantage of the detailed World Bank survey, we therefore examine the effects of other CEO characteristics on the corporate insurance decision.

\subsection{Corporate Governance and Corporate Insurance}

In essence, corporate governance is concerned with the way managerial performance is monitored and controlled in order to ensure compliance with owners' wealth maximization objectives (Raheja, 2005). Corporate risk management theories show that, in the presence of market imperfections, appropriate insurance can enhance firm value via: a) lowering the firm's costs of financial distress (both direct and indirect) (e.g., Mayers and Smith, 1982); b) mitigating the assets substitution problem (MacMinn, 1987) and the underinvestment problems (MacMinn, 1987; Mayers and Smith, 1987; Garven and MacMinn, 1993), thereby coordinating a firm’s financing and investment activities; c) forcing managers to invest in some positive-NPV loss control and safety projects that otherwise may be passed up by managers who focus on short-term profit targets at the time of insurance underwriting (Mayers and Smith, 1982; Campbell and Kracaw, 1987). In property insurance, insurers often provide "free" and "quality-bonded" safety inspections and loss control advice for their clients ${ }^{12}$, which can be valuable for Chinese firms that often lack risk management expertise. ${ }^{13}$ As a result, strong monitoring of the CEO may therefore induce or force the managers

\footnotetext{
12 The quality of such service is generally assured, as otherwise insurers will need to bear the subsequent losses (e.g., claims payments and/or loss of business) arising from poor quality advisory services.

13 There is some evidence supporting the benefits of corporate risk management. For example, Graham and Rogers (2002) find that derivative hedging increases a firm's debt capacity. Allayannis and Weston (2001) report a hedging premium of 5\% for a sample of U.S. firms using foreign currency derivatives. Carter, Rogers and Simkins (2006) find that jet fuel hedging by U.S. airlines increases firm value in the magnitude of $7 \sim 10 \%$ through the reduction in underinvestment costs. As for the effects of corporate insurance, Zou and Adams (2008) find that in China where listed companies rely heavily on private debt (e.g., bank loans) because the issue of equity and bonds are tightly regulated, the purchases of property insurance increase debt capacity and marginally lower interest costs. Zou (2009) shows that more property insurance in China is associated with a higher firm value (measured by Tobin's $q$ ) for most firms, however, excessive insurance appears to be value destroying. His test also suggests that one avenue
} 
to purchase property insurance that represents a pure hedge (indemnity) against potentially severe accidental losses. Therefore, we expect strong monitoring to encourage a firm to participate in the purchase of property insurance (i.e., the participation decision).

As for the effect of corporate governance on the extent of property insurance, the prediction is ambiguous because strong monitoring should reduce the excessive use of property insurance for managerial self interest. In addition, property insurance is an indemnity contract in nature and the amount of insurance settlement is capped at the amount of actual loss and the coverage purchased, whichever is lower. Indeed, Zou (2009) shows that the relation between the amount of property insurance and firm value is an inverted U-shape and excessive insurance beyond the inflection point can decrease firm value because the extra insurance premium paid does not bring additional economic benefit. With strong monitoring, managers may therefore have to more carefully evaluate the optimal insurance coverage that is needed. A further complication in the assessment of the amount of insurance purchased is that managers may trade off insurance premiums and deductibles in order to obtain the same amount of coverage. ${ }^{14}$ This suggests that the insurance volume decision is inherently more complicated than the insurance participation decision. Therefore, we leave the effect of corporate governance on the extent of property insurance use as an empirical question.

Since hedging decisions can be induced by agency incentives of managers and/or reflect strong monitoring, we expect that in firms with strong monitoring, corporate governance ensures that shareholder-manager interests are more aligned and so the chance of purchasing insurance for managerial private benefits is lowered. In contrast, in firms with lax monitoring, the corporate purchase of property insurance is more likely to reflect managerial self interest. In other words, the determinants of corporate insurance uses (particularly those reflecting managerial incentives) should differ between firms with strong and lax monitoring of CEOs.

\section{Sample and Variables}

This section describes data and defines the proxies of monitoring and CEO incentives.

\subsection{Data}

Our data were obtained from a World Bank's (2004) investment climate survey of 18 cities

for insurance to increase firm value is that insurance helps secure debt financing and increase investment.

${ }^{14}$ As our model of insurance extent relies on insurance premiums, we may suffer omitted variable bias due to unobservable factors such as the chosen level of deductibles. We thank an anonymous referee for suggesting this. 
across China's different geographical regions (i.e., Northeast, Coastal, Central, Southwest and Northwest with each region roughly having $100-150$ firms), and the total number of firm is 2,400 . The survey data include financial information on sales, profits, assets and liabilities, expenses, plus information on board composition, relations with government for the year 2002. For the purpose of our study, the survey provides corporate information on property insurance premium expenditure in 2002. Some key financial variables are also provided for the years 2000-2001. Cull and Xu (2005) use the same dataset in their study of corporate reinvestment in China. After dropping observations with missing values on the variables we use, we are left with 1,881 firms. As discussed in the introduction part of the paper, this World Bank survey dataset offers several key advantages over insurance data collected from voluntary insurance disclosure in listed companies' annual reports.

\subsection{Proxies and Variable Measurements}

\subsubsection{Proxies for the CEO incentives}

We include several proxies of the CEO's personal wealth vested and human capital invested in the firm - i.e., the proportion of the CEO's holding of company shares and a dummy for the existence of a bonus scheme, ${ }^{15}$ and the CEO's total cash compensation (salary and cash bonus) (defined as the $\log$ of total remuneration as a multiple of the total average pay of ordinary employees in the firm). ${ }^{16}$ Since the mean level of managerial ownership is low and there is not a stock option plan in our sample period in China, salary and cash bonus should be the majority of a CEO's employment income and hence it proxies for a CEO's personal wealth vested in the firm.

In addition, managers may have firm-specific human capital that cannot be easily diversified. As in May (1995), we include a CEO's tenure in the current position as a proxy for the CEO's human capital tied up in the firm or managerial entrenchment. The longer the CEO has been in the current position, the greater the motivation for the CEO to insure in order to protect his/her job security or private benefits he/she extracts from the firm. ${ }^{17}$

\footnotetext{
${ }^{15}$ As many sample firms are not listed and there was no stock option scheme in our sample period, we could not include Delta (the dollar change in a CEO's stock and option portfolio for a $1 \%$ change in stock price) and Vega (the dollar change in a CEO's option holdings for a $1 \%$ change in stock return volatility) as measures for managerial risk-taking (see Rogers, 2002).

${ }^{16}$ The World Bank survey does not provide data on the absolute amount of CEO compensation but rather a multiple of CEO annual compensation relative to the average pay of ordinary employees.

${ }^{17}$ When a manager has little opportunity to move within and out of the industry and when he/she has been in the CEO position for a longer time, his/her human capital becomes more firm-specific. We thus include the interaction between CEO tenure and a dummy for oligopolistic industry (if there are less than six competitors in a firm's
} 
In China's SOEs, the CEO may also serve as a secretary to the ruling Communist Party within the firm and thus act as a 'quasi government official' with a political career; the status as a Party secretary could proxy for their political career prospect. In order to protect their political career and to avoid being blamed for neglect of duty or for incompetence in management, these politically connected CEOs may have incentives to insure the firm (Zou and Adams, 2008). We thus include a dummy variable that equals 1 if the CEO is the Party secretary in the firm.

We also include a dummy variable that equals 1 if the CEO was a manager before joining the current firm as a proxy for CEO's professionalism. The signaling theory literature (e.g., DeMazro and Duffie, 1995; Breeden and Viswanathan, 1996; Doherty, 2000) argues that high-quality managers may use risk management to signal private information regarding their managerial ability to outside investors in order to command higher compensation. Specifically, managers can hedge incidental risks that are beyond their effective control (e.g., the loss arising from an occurrence of a natural disaster) to reduce "noise" in their assessed performance and make their productivity more transparent. Whether the CEO was a manager could also proxy for managers' reputational capital since a seasoned manager should have better reputation than a newly appointed manager and risk management is a way to protect their reputational capital.

Finally, we explicitly include a dummy variable that takes the value 1 when a firm uses the safety of operation as an evaluation criterion in managerial incentive-performance contracts. CEOs of such firms are expected to have added incentives to consider property insurance because the firm can benefit from the insurer's real service in regular safety inspections, loss prevention advice, and loss recovery if an accidental loss occurs.

\subsubsection{Proxies for monitoring mechanisms}

Following the corporate governance literature and taking account of the institutional setting in China, we measure corporate monitoring by whether a firm is privately owned, has foreign institutional ownership or not, a joint-stock company (including publicly listed), has a board of directors whose members hold company shares, uses external auditing and appoints independent

industry, i.e., variable Competition $<=2$, see Table 1) as another proxy for CEO's firm-specific human capital (see Becker, 1962, p.18). In unreported results, we find the coefficient of the interaction term is positive, but insignificant in the Probit and Tobit models of insurance (with a t-value about 1.40). 
directors, separates the CEO and board Chairman positions, deals with a bank having a collateral requirement. The rationale for examining these monitoring mechanisms is discussed briefly below.

There are both state-owned enterprises (SOEs) and private (small and medium-sized (SME)) firms in China. Allen, Qian and Qian (2005) report that in China SMEs now dominate SOEs both in terms of their contribution to the national economy and their annual growth rates. Compared with private firms, SOEs are known to suffer from vague ownership identity, weak property rights, severe owner-manager agency problems, lax monitoring and the pursuit of non-economic objectives (e.g., maintaining employment) (e.g., see Boycko, Shleifer and Vishny, 1995; Cull and Xu, 2005). Lin et al. (2008) also report that Chinese SOEs have historically been associated with poor governance and inefficiency. In contrast, private SMEs are truly market-oriented entities responsible for their own performance and tend to be more efficient than SOEs. We therefore include a SOE firm dummy (with 1 denoting state and collective ownership $\geq 50 \%$ ). We aggregate collective ownership with state ownership because collectively-owned enterprises in China are essentially quasi-SOEs (Cull and Xu, 2005). Foreign institutional investors investing in China are likely to be concerned about the operation and risk management of the firms in which they invest. Indeed, institutional foreign ownership in our sample firms tended to have a low liquidity because they mainly invest in unlisted companies. ${ }^{18}$ Therefore, a high level of foreign founder ownership is expected to be positively correlated with greater incentives to monitor CEOs.

China's Companies Law (1993) imposes more stringent governance requirements on joint-stock companies than on limited-liability companies (LLCs) in terms of the composition of the board of directors and the supervisory board, financial reporting and auditing requirement. ${ }^{19}$ Joint-stock companies that are listed are further subject to the regulations of the CSRC and the listing rules of the Shanghai and Shenzen Stock Exchanges. We therefore argue that CEOs of joint stock companies are subject to more monitoring than their counterparts in other corporate forms. ${ }^{20}$

In addition to certifying whether or not published financial statements are 'true and fair',

\footnotetext{
18 The qualified foreign institutional investors (QFII) program that allows foreign institutional investors to directly invest in domestic A-shares became effective in December 2002.

${ }^{19}$ For example, while joint-stock companies must have a board of directors and supervisory board, small LLCs can choose to have just one executive director and to have one or two supervisors instead of a supervisory board.

${ }^{20}$ We note that a joint stock company may have a lower demand for insurance than a LLC if its investors are well diversified. We thank an anonymous referee for suggesting this.
} 
external auditing in China often includes an evaluation of firms' internal control and risk management systems. Accordingly, we expect that firms subject to annual external auditing are likely to have extra monitoring of CEOs than those firms that are not externally audited.

We include three board composition variables as monitoring proxies. A more independent board and a board that separates the CEO and board chairman positions imply stronger monitoring and such firms may be more likely to consider value-increasing corporate risk management (via insurance). Borokhovich et al. (2004) report that the proportion of outside directors is positively related to the corporate use of derivatives in the U.S. Alternatively, board independence and the separation of the CEO and board chairman positions may help to reduce the purchase of corporate insurance out of managerial self-interests. We also include the proportion of directors owning company shares as an additional monitoring proxy. Directors owning company shares may find better alignment between their interests and those of shareholders and so may have stronger incentives to monitor CEO behavior.

Many Chinese firms rely on debt financing (e.g., bank loans). To proxy for the monitoring incentives and efforts of banks (e.g., see Yamori, 1999), we include a dummy variable on whether the lender has a collateral requirement as a monitoring mechanism for the shareholder/CEO-debtholder incentive conflicts. ${ }^{21}$

\subsubsection{Control variables for corporate property insurance}

To separate out the effects of governance monitoring and CEO incentives on insurance decisions, we control for other factors affecting a firm's property insurance decisions. Following prior studies (e.g., Mayers and Smith, 1982; Hoyt and Khang, 2000; Zou and Adams, 2006), we include (lagged) leverage, firm size; (lagged) growth opportunities (proxied by research and development (R\&D) spending and the capital expenditure to sales ratio in 2001). Please see Table 1 for detailed definitions of all the variables. Theory predicts that small firms, firms with high leverage and/or entities with greater growth opportunities are more likely to purchase property insurance than other firms. This is because small firms are more vulnerable to financial shocks and can benefit more from insurers' risk management and loss control services. High leverage and

\footnotetext{
${ }^{21}$ The question in the World Bank survey asks "Did the (most recent loan) financing require collateral?" Note that our measure of proxy may be noisy as it only concerns the monitoring effort of the most recent loan, and arguably it may to some extent reflect the credit risk of the borrower.
} 
growth firms can also use insurance to lower the cost of financial distress, to mitigate the underinvestment problems, and/or to increase debt capacity (Zou and Adams, 2008). The agency costs of the underinvestment problem are particularly high for firms having both high leverage and growth opportunities. Therefore, following Graham and Rogers (2002), we interact leverage with growth opportunities proxies. ${ }^{22}$

We include a firm's asset tangibility ratio to control for the effects on insurance decisions due to differences in firm-specific asset structure. We interact leverage with the asset tangibility ratio to capture the possibility that the purchase of property insurance may concomitantly depend upon the degree of leverage and the amounts of tangible assets in place (such an interaction effect has been often neglected in prior insurance studies). We include a firm's current ratio as a proxy for a firm's ability of self insurance. Regan and Hur (2007) find that Korean firms with a significant amount of export business tends to purchase more insurance to mitigate the significant uncertainties and loss risks involved in the exporting process, and we thus include the average fraction of export sales to total sales over the period 1999-2001 as a further control.

The interaction between product market competition and corporate risk management has gained increasing research attention. Therefore, the impact of product-market competition on insurance use and its interaction with corporate governance are interesting questions and, to our knowledge, have not been explicitly tested before. We control for the number of firms in an industry as a proxy for market competition and expect it to have a positive effect on the use of property insurance because of two reasons. First, a firm faces the predation risk of losing its market share and investment opportunities to rivals if it cannot fully take advantages of these opportunities. Firms in competitive industries may be more likely to hedge their risks than firms in uncompetitive industries to manage the predation risk that may arise from a major accidental loss event to their strategic benefits (Brander and Lewis, 1986; Adam, Dasgupta and Titman, 2007; Haushalter, Klasa and Maxwell, 2007). In particular, Seog (2006) shows that in a duopoly market, purchasing insurance allows the firm to be more aggressive in the output market, thereby enhancing its competitiveness relative to its competitor. In addition, the monopoly power generated from the lack of competition may allow

\footnotetext{
22 The two continuous component variables are centered before constructing the interaction term to avoid collinearity and the centered component variables also enter the regression (see Jaccard, Turrisi and Wan, 1990).
} 
managers to increase product/service prices to cover accidental losses instead of pursuing an effective risk management strategy. We also include a dummy variable denoting whether there is at least an employee representative sitting on the board of directors. Fauver and Fuerst (2006) argue that labor representation on German supervisory boards provides a powerful means of monitoring of managers who shirk, take perks, and other opportunistic behaviors and confers valuable first-hand operational knowledge to the board's decision making. In addition, in protecting their own interests, employee representatives indirectly protect the interests of minority shareholders. Consistent with this argument, they find labor seats on the supervisory board increases firm value. In corporate insurance decisions, we argue that on the one hand, labor board members may help encourage the purchase of insurance in order to protect employment and the interests of other stakeholders (e.g., shareholders may benefit via a lowered risk premium demanded by employees and other stakeholders). On the other hand, labor board members may help monitor the purchase of insurance for managers' self interest.

Finally, nine industry dummies categorized by the first-digit industry code are included to control for risk-profile differences across different business lines. As an important improvement over prior insurance studies (e.g., Zou and Adams, 2006, 2008), we also include 17 city dummies in our models to control for the effects of different geographical risk exposures (e.g., some firms may be located in earthquake or flood prone areas), economic development, the legal and safety environment, and the development of local insurance markets on the corporate purchase of insurance. As a result, these city-level fixed effects can help to control for the effects of omitted variables; this couples with our use of robust standard errors clustered at the city level that allows cross-sectional correlation enables us to have a more robust test of our hypotheses. In fact, the empirical results show that most city dummies are statistically significant at the 0.01 level (results are not reported for brevity).

[Insert Table 1 here]

\section{Results}

In this part of the paper we present and discuss our empirical results.

\subsection{Summary Statistics}

The summary descriptive statistics for our sample are given in Table 2. 
[Insert Table 2 here]

It shows that about $58 \%$ of our sample firms purchased property insurance in 2002 . The median value of insurance premiums to the book value of their physical assets (fixed assets and inventory) is $0.279 \%$ in insured firms. However, one should not hasten to conclude that such level of insurance use is trivial given that the data presented here are based on insurance premiums rather than on coverage. We can divide the median insurance intensity $(0.279 \%)$ by $0.3 \%$ to gain a rough idea of the percentage of coverage relative to beginning-of-period tangible assets and the proportion covered is over $90 \%$ - an economically significant figure. ${ }^{23}$ In order to gauge whether or not the extent of insurance of our sample firms is significant within an international context, we consider the summary statistics based on the 73 publicly traded U.S. firms for the period 1991 through 2002 used in Aunon-Nerin and Ehling (2008). They report a premium-to-tangible assets ratio of $0.045 \%$ and a coverage-to-tangible assets ratio of $5 \%$, which are lower than the figures of our sample firms. One reason for such a huge difference in the coverage-to-tangible assets ratio may be their sample firms are much larger. Comparing the mix of insurance users and non-users in our sample and that in the sample used in Zou and Adams (2008) (where about 90\% of firms purchased property insurance), our sample has a more balanced mix of insurance users and non-users and so should be better suited for a powerful test of the insurance participation decision.

We also compare the characteristics of insurance users and non-users. We find that firms that insure are larger, have more capital expenditure and R\&D spending and higher tangible asset intensity, export more, have a higher level of foreign institutional ownership and a higher proportion of independent directors and a higher monitoring index. In addition, CEOs of firms that insure tend to earn more salary and bonus relative to average employees. Moreover, Chi-square tests suggest the state-owned firm dummy, joint-stock firm dummy, audit dummy, dummy for "CEO was a manager", bonus plan dummy, dummy for using safety of operation as an evaluation criterion, dummy for having an employee representative on the board of directors, dummy for "CEO is a Party secretary" are all significantly related to the insurance decision. These results provide preliminary support for the need to examine these variables in our analysis.

\footnotetext{
${ }^{23}$ Property insurance premiums rates vary according to the nature of the business. $0.3 \%$ is roughly the mean of the premiums rates charged by the Peoples' Insurance Company of China (PICC) (a major insurance provider in China) on an average industrial business basis.
} 


\subsection{Empirical Results from Multivariate Regressions}

We first employ a Probit model to investigate the relations between governance variables, CEO incentives and a firm's likelihood of purchasing property insurance, while controlling for other firm characteristics, industry and city dummies. We use heteroskedasticity robust standard errors clustered at the city level in computing $p$-values. Therefore, we explicitly allow for the cross-sectional correlation caused by city-specific factors (e.g., area-specific catastrophe risk like flooding and difference in safety standard \& legal environment among different cities) and this treatment has been shown to be important in deriving robust and reliable results in business and economic studies (Petersen, 2008). The empirical results are presented in Column 1 of Table 3. In order to evaluate the magnitude of the effects, marginal effects evaluated at sample means for continuous variables and the discrete change from 0 to 1 for dummy variables are reported.

[Insert Table 3 here]

As can be seen from Table 3, CEO cash compensation (salary and bonus) is positively and significantly associated with the incidence of property insurance. However, the existence of a bonus plan and CEO stock ownership do not exert significant impacts on the likelihood of property insurance. As we discuss earlier, in China, salary and cash bonus should account for the majority of a CEO's income derived from the company and can be regarded as a proxy for the CEO's personal wealth vested in the firm. The finding of a positive correlation between CEO cash compensation and the incidence of insurance provides some support for the self interest motive of CEOs. The coefficient of the bonus plan dummy on the corporate use of insurance is not significant. Perhaps, the effect of a bonus plan has been partially captured by our measure of CEO cash compensation that includes bonus payments; however, our data do not allow us to separate the bonus part. The theory is divided as to the effect of managerial ownership on corporate hedging, and consistent with the findings of Zou and Adams (2006; 2008), we find no evidence of a significant impact of managerial ownership on the incidence of property insurance.

Other CEO characteristics also seem to play important roles in insurance participation decisions. Specifically, CEO tenure, which May (1995) used as a proxy for CEO's human capital invested in the firm, and whether the CEO was a manager before are positively and significantly associated with the chance of having property insurance. It could be argued that a CEO who was a manager in 
another firm may have more reputational capital than a newly appointed CEO. Therefore, the results on CEO tenure and whether the $\mathrm{CEO}$ was a manager $\mathrm{CEO}$ are consistent with the managerial self-interest motive of using insurance - the purchase of insurance can help protect their reputation and/or enhance their job security. Alternatively, the results of both variables are consistent with the notion that high-quality managers may manage risks to signal private information regarding their managerial ability to outside investors in order to command higher compensation (e.g., DeMazro and Duffie, 1995; Breeden and Viswanathan, 1996; Doherty, 2000). This is because "noise" in firm performance arising from risks that are beyond the control of managers can be reduced so that performance better reflects managers' ability and productivity.

Our conjecture on managers' self-interest motive of purchasing insurance is further strengthened by the strong positive effect of CEO being a Party secretary on the incidence of property insurance. Fan et al. (2007) argue that politically connected managers are quasi-politicians, less professional, and have a private agenda of pursuing a political career. Our finding is also consistent with the view expressed in Zou and Adams (2008) that in SOEs, (politically-connected) CEOs may insure property risks to mitigate the effects of possible neglect of duty and protect their political career prospects.

Regarding the effects of the variables reflecting CEO incentives, the incidence of property insurance use increases with the proportion of foreign institutional ownership, external audit requirement of a firm's financial statements, the separation of the CEO and board chairman positions, the proportion of directors owning company shares. As discussed previously, these four variables indicate stronger monitoring of CEOs and hence there is some evidence that strong monitoring of CEOs encourages the purchase of property insurance to protect the firm against the fortuitous asset-damage risks. However, the coefficients of state ownership ${ }^{24}$, joint-stock firms dummy, the proportion of independent directors, and bank collateral requirement are not statistically significant though the signs of these coefficients are mostly positive.

Among the control variables, the coefficient estimate for firm size is positive and significant at the $1 \%$ level, suggesting that larger firms are more likely to insure their assets than small companies.

\footnotetext{
${ }^{24}$ We also use an alternative State ownership dummy that equals 1 if the government is the largest shareholder in a firm and find it has a correlation of 0.987 with the original State ownership dummy. Unreported regression results from using the alternative variable produced essentially the same results.
} 
This finding is consistent with the results reported in Zou et al. (2003). As expected, companies with a greater degree of asset tangibility are more likely to purchase property insurance to manage asset-loss risks. Proxies for underinvestment problems (leverage, growth opportunities measures, and their interaction terms with leverage) are not found to have important effects on the incidence of property insurance.

The analysis so far has focused on the incidence of property insurance. We now examine the effects of CEO incentives and governance monitoring mechanisms on the amount of insurance spending. As in Hoyt and Khang (2000), Zou and Adams (2006, 2008) and Regan and Hur (2007), we use a premiums to assets ratio as the dependent variable (defined as property insurance spending divided by prior year-end value of fixed assets and inventory). While our measure of the extent of insurance is consistent with prior studies, it is imprecise in the sense that premium rates may be affected by the risk profile of the insured and the choice of deductibles by the insured (e.g., see Aunon-Nerin and Ehling, 2008). Strictly speaking, we need to use actual indemnity coverage of corporate assets, which unfortunately is not available from our data. This represents an unavoidable limitation of our analysis. However, this concern is, to some extent, mitigated by the universal premium rate regulation in property insurance in China that requires insurance companies to follow a guideline issued by the China Insurance Regulatory Commission (CIRC) regarding risk classifications and applicable rates in underwriting (see Zou et al., 2003).

In the present study, we follow most of the risk management literature (e.g., Tufano, 1996; Graham and Rogers, 2002; Dionne and Triki, 2004; 2005) to use a Tobit model to analyze the insurance volume decisions. ${ }^{25}$ The Tobit results presented in Column (2) of Table 3 show that only two monitoring mechanisms (the audit dummy and the separation of CEO and Chairman) continue to have a positive effect on the extent of insurance. The coefficients of all but one variable reflecting CEO incentives are statistically insignificant in the insurance intensity model. The only

\footnotetext{
${ }^{25}$ As pointed out by an anonymous referee, some non-insured firms are observed to have zero insurance because they are constrained from taking on "negative insurance" (even if it might be an optimal choice to them), or because their risk management incentives are below a certain threshold. In this case, a Tobit analysis suffices. In unreported results, we also estimate a Cragg model. While the monitoring index is positive and insignificant in the pooled analysis in the Cragg model, the split-sample analysis using the median of the monitoring index as a cutoff reveals similar (albeit weaker) differences between firms with strong and poor monitoring. Such differences in results may be because the Cragg model only includes the firms carrying insurance, whereas the Tobit model uses all firms.
} 
(marginally) significant CEO incentive variable is the safety evaluation dummy. Its positive coefficient suggests that when a firm uses safety of operation as a performance evaluation criterion in incentive-based compensation, the firm tends to purchase more property insurance. Purchasing property insurance enables a firm to access the insurer's advice on loss prevention and control in addition to the coverage secured, and as a result, the safety of operation may improve and managers may score higher in performance evaluation.

Nevertheless, we see more success with modeling the insurance volume decisions among control variables. The coefficient of asset tangibility alone is negative and statistically significant, suggesting that firms do not purchase insurance in amounts proportionate to asset tangibility though firms with higher asset tangibility intensity are more likely to purchase insurance in the first place. While the coefficient of leverage is not significant, the coefficient of the interaction term between leverage and asset tangibility is, as expected, positive and significant, implying firms with both high leverage and more tangible assets tend to purchase more property insurance than other firms. Accounting for the interaction term between leverage and tangible assets may help to reconcile the previously mixed findings regarding the effect of leverage on the extent of property insurance. For example, the insignificance of leverage in Yamori (1999) and Zou and Adams (2006), its significant positive effect in Hoyt and Khang (2000) and negative significant impact in Zou et al. (2003) and Regan and Hur (2007).

In addition, the coefficient of the interaction between a firm's R\&D intensity (proxy for growth opportunities) and leverage is positively associated with the extent of property insurance, suggesting growth firms with high leverage tend to have a higher demand for insurance in order to reduce firm risk and/or mitigate the underinvestment problem. However, other proxies for the underinvestment problems (e.g., capital expenditure and its interaction term with leverage) do not show significant impacts on the extent of property insurance.

We also find that a firm's liquidity ratio is positively correlated with the extent of insurance. While this result is not in line with the theory, it is consistent with the finding of Zou and Adams (2006) and Regan and Hur (2007). It is possible that firms using external post-loss financing (e.g., insurance) as a complement to internal current assets. Alternatively, when a firm's liquidity is low, financial constraints limit the purchase of property insurance. As in Regan and Hur (2007), we find 
that a firm tends to use more property insurance when it has a large fraction of export sales. Finally, a firm appears to purchase more property insurance when its board of directors has employee representatives. This provides some support for the monitoring role that employee board members may play in board decisions documented in Fauver and Fuerst (2006). In such companies, corporate insurance decisions also need to consider the interests of other stakeholders (e.g., employees) instead of only shareholders, debtholders and managers. This is a result that has not been reported in the insurance literature.

\subsection{Results from using a monitoring index}

Previously we have examined the effects of individual governance monitoring mechanisms on the use of property insurance. In order to gauge the overall effect of monitoring on corporate insurance decisions, in the spirit of Gompers, Ishi and Metrick (2006), we construct a 'monitoring index' that equals to the sum of the State-owned firm dummy (recoded to let one denote private firms), joint stock company dummy, audit dummy, board dummy, CEO-Chairman duality (recoded to let one denote the separation of CEO and Chairman positions), and the dummy for the existence of independent directors on the board, whether board ownership is above the sample median, and whether there is a bank collateral requirement. The index ranges from $0 \sim 7$, with a higher value for stronger monitoring. The Probit and Tobit regression results from using the monitoring index are presented in Columns (3) and (4) of Table 3.

As can be seen from Table 3, the monitoring index is found to be positively associated with the likelihood and the extent of property insurance purchase. Specifically, one score increase in the monitoring index increases the chance of insurance by about $4 \%$. The results on proxies for CEO incentives are similar to our previous findings. The results on control variables are also broadly consistent with the results from Columns (1) and (2) of Table 3 except that the coefficient of firm size now becomes positive and statistically significant in the Tobit model.

\subsection{Do firms subject to different monitoring purchase property insurance in different ways?}

So far, we have found some evidence that both CEO incentives and monitoring may motivate the purchase of property insurance. Since governance monitoring may help prevent or reduce the purchase of property insurance induced by managerial self interest, it should be interesting to examine whether firms subject to strong monitoring and weak monitoring purchase property 
insurance in different ways. This section conducts split-sample analysis based on whether a firm's monitoring index is above sample median index or not. The results are presented in Table 4. (The monitoring index does not show up significantly in any of the sub-samples and so is excluded from the split-sample analysis)

\section{[Insert Table 4 here]}

The results from the split-sample probit analysis are revealing. The coefficients of the most of the variables reflecting CEO incentives are positive and statistically significant only in the sub-sample in which firms have a monitoring index below or equal to the sample median (i.e., 3 ). Specifically, a higher level of CEO cash compensation, a longer CEO tenure, CEO being the Party secretary and holding a past managerial position all lead to a higher chance of property insurance purchase in firms subject to lax monitoring. In contrast, these patterns do not exist in the sub-sample with strong monitoring. These results reinforce our previous findings that managerial incentives to protect their financial interest, human capital and/or political career prospect play a role in the corporate insurance decision in China. The results also suggest that governance monitoring plays a role in attenuating the purchase of property insurance for mangers' self-interest.

It is also assuring to note that there are some key differences in the economic determinants of the insurance participation decision between the two sub-samples. For example, in the sample subject to strong monitoring, firms with high capital expenditure and hence more growth opportunities are more likely to purchase property insurance, which is consistent with using insurance to mitigate the underinvestment problem. In addition, firms with a low liquidity ratio are more likely to insure to prevent financial distress caused by a liquidity crunch following a major accidental loss. These patterns, however, are not present in the sub-sample subject to lax monitoring. Therefore, compared with firms with lax monitoring, the insurance participation decision in the firms with strong monitoring is more in line with the prediction of economic theories focusing on shareholder interests. Finally, it is interesting to note that a higher extent of product market competition only increase the incidence of property insurance use in firms with strong monitoring, suggesting the effect of the interaction between product market competition and governance mechanisms on the corporate purchase of insurance. To our knowledge, this is the first empirical evidence regarding the effect of product market competition on the corporate purchase of insurance 
in the literature.

The results from the Tobit split-sample analysis also reveal some key differences in the insurance patterns of the firms with strong monitoring and firms with lax monitoring. Similar to the Probit results, CEO tenure and the variable "CEO was a manager" only have a positive and significant effect on the extent of insurance in the sub-sample with lax monitoring, and growth opportunity measure (R\&D intensity) has a positive and significant effect on the extent of insurance only in the sub-sample with good monitoring. Also, related to the Probit results, laxly monitored firms purchase more insurance when they have a higher liquidity ratio, suggesting the positive relation between liquidity ratio and the extent of insurance observed in the pooled sample analysis is mainly driven by the laxly monitored firms. Therefore, the difference in governance may be one fruitful avenue to explain the observed (and somewhat surprising) positive relation between corporate insurance and liquidity ratios in prior studies (Zou and Adams, 2007; Regan and Hur, 2007). In addition, when a firm uses safety of operations as a performance evaluation criterion in managerial incentive contracts, firms tend to purchase more property insurance when managers are subject to less monitoring. This result provides additional support for the purchase of property insurance for the interests of managers in firms with lax monitoring. However, the interaction Asset tangibility $\times$ Leverage unexpectedly has a positive and significant effect on the extent of insurance in the firms subject to lax monitoring but not in firms with strong monitoring.

\subsection{Endogeneity of managerial compensation}

By shifting asset-loss risk to insurance companies and lowering the chance of financial distress, the job loss risk borne by managers is also reduced. In turn, companies may be able to reduce the risk premiums paid to managers (Mayers and Smith, 1982; Campbell and Kracaw, 1987; Han, 1996). More importantly, the benefit of insurance could go well beyond the reduction in the risk premiums paid by the firm by facilitating the adoption of incentive-based compensation. Indeed, Holmstrom and Milgrom (1987) argue that incentive compensation should not be based on noisy performance metrics. Aggarwal and Samwick (1999) find that firms with highly volatile stocks are least willing to offer incentive-based compensation as it imposes large risk on managers. As a result, firms should have incentives to insure to reduce cash flow volatility in order to use bonus plans that rely on short-term accounting measures (Ryan and Wiggins, 2001). Campbell and Kracaw (1987) also 
show that the optimal incentive contract will generally depend on the ability of the manager to insure or hedge firm-specific risk. The above reasoning suggests the endogeneity of managerial compensation with respect to insurance. ${ }^{26}$

The endogeneity issue, however, may not be a serious concern in our analysis since we do not find managerial ownership and the existence of a bonus plan have a significant effect on the corporate use of insurance. The only variable that shows a significant impact is CEO cash compensation. Nevertheless, we provide a robustness check in this section by using an instrumental variable approach. Specifically, we instrument CEO cash compensation, managerial ownership, and bonus plan by the average of the corresponding variable in firms of the same industry, district, and the same owner type (i.e., whether a firm is state-controlled or not). Our approach is informed by the recent development economics literature (Fisman and Svesson, 2007). Specifically, Fisman and Svesson (2007) try to overcome a similar endogeneity problem by using industry-location averages as instruments. In our case, firms in the same location and industry may compete for the small pool of managerial talents in the local labor market (in China there is still residence permit control that restricts people's mobility across different regions and there is not a nationwide developed managerial labor market). In order to attract good managers, a firm's managerial compensation may crucially depend on the compensation offered by competitors. We further augment industry-location match by requiring local firms to have the same type of owner. This is because the pay of SOE managers (whose pay may follow a civil servant rank) may differ from the pay of private firm managers. Our industry-location-ownership averages are highly correlated with the corresponding compensation variable (with correlation coefficients around 0.80). However, as a priori these industry-location-ownership averages are not expected to affect a firm's insurance decisions in a systematic way. We repeat our analyses in Tables 3 and 4 using these instrument variables. In unreported results, we find no significant changes in the results of the three compensation variables (i.e., CEO cash compensation has a positive effect on the incidence of insurance in the pooled models in Table 3, and in firms with lax monitoring in Table 4; while CEO ownership and bonus plan do not have any significant effect) and other variables in the Probit models. There are, however,

\footnotetext{
${ }^{26}$ We thank an anonymous referee for raising this point.
} 
some changes in the results of the Tobit models and they are reported in Table 5.

[Insert Table 5 here]

The key change in the results is that the coefficient of the instrumented CEO cash compensation is now positive and statistically significant in the pooled Tobit models (Column (1) and (2) corresponds to the pooled Tobit model in Column (2) and (4) of Table 3, respectively). More importantly, it is also positive and statistically significant in firms subject to lax monitoring but not in firms with strong monitoring. These results are consistent with the argument that CEOs have incentives to insure for self interest and strong monitoring helps curb such opportunistic behavior. Other results are qualitatively unchanged. Overall, we do not find CEO stock ownership and bonus plan have significant impacts on corporate insurance decisions in China.

\section{Conclusion}

Using a unique World Bank firm-level survey dataset on corporate insurance in China, this study empirically tests the effects of CEO incentives and governance monitoring of CEO behaviors on corporate risk management via insurance. The dataset is well suited for our investigation because it comprises firms with significant variations in corporate governance practices and provides detailed information about CEO incentives. We find: (a) both CEO personal incentives and governance monitoring mechanisms can induce corporate insurance; (b) firms subject to different monitoring tend to purchase property insurance for different purposes. Specifically, the purchase of property insurance for managerial self interest is only prevalent in firms subject to lax monitoring and the determinants of insurance purchase are more in line with the prediction of economic theories in firms with strong monitoring.

While the linkage between corporate governance and corporate risk management has gained increasing research attention in recent year, almost all prior works have used derivatives data. Our study adds to this emerging literature by providing evidence in the context of risk management via insurance. In addition, our study provides several new tests and insights regarding the determinants of corporate purchase of insurance. For example, we are the first to show the empirical linkage between external auditing, product market competition, board labor representation and corporate use of insurance. Future studies would benefit from examining this issue in both developed and other developing markets when insurance data becomes publicly available. 


\section{References}

Adam, T., S. Dasgupta, and S. Titman, 2007, Financial Constraints, Competition and Hedging in Industry Equilibrium, Journal of Finance, 62: 2445-2473.

Adams, M. B., P. Hardwick, and H. Zou, 2008, Reinsurance and Corporate Taxation in the United Kingdom Life Insurance Industry, Journal of Banking and Finance, 32: 101-115.

Aggarwal, R. K., and A. A. Samwick, 1999, The Other Side of the Trade-off: The Impact of Risk on Executive Compensation, Journal of Political Economy, 107: 65-105.

Aivazian, V. A., Y. Ge, and J. Qiu, 2005, Corporate Governance and Manager Turnover: An Unusual Social Experiment, Journal of Banking and Finance, 29: 1459-1481.

Allayannis, G., and J. P. Weston, 2001, The Use of Foreign Currency Derivatives and Firm Market Value, Review of Financial Studies, 14: 243-276.

Allayannis, G., U. Lel, and D. Miller, 2003, Corporate Governance and the Hedging Premium around the World, Working Paper, Darden Graduate School of Business Administration, University of Virginia.

Allen, F., J. Qian, and M. Qian, 2005, Law, Finance, and Economic Growth in China, Journal of Financial Economics, 77: 57-116.

Aunon-Nerin, D., and P. Ehling, 2008, Why Firms Purchase Property Insurance? Journal of Financial Economics, 90: 298-312.

Bai, C-E., Q, Liu, J. Lu, F. M. Song, and J. Zhang, 2004, Corporate Governance and Market Valuation in China, Journal of Comparative Economics, 32: 599-616.

Becker, G. S., 1962, Investment in Human Capital: A Theoretical Analysis, Journal of Political Economy, 70: 9-49.

Berkmann, H., R. A. Cole, and J. Fu, 2010, Political Connections and Minority-Shareholder Protection: Evidence from Securities-Market Regulation in China, Journal of Financial and Quantitative Analysis, 45: in press.

Borokhovich, K. A., K. R. Brunarski, C. E. Crutchley, and B. J. Simkins, 2004, Board Composition and Corporate Use of Interest Rate Derivatives, Journal of Financial Research, 28: 199-216.

Boycko, M., A. Shleifer, and R. Vishny, 1995, Privatizing Russia (Cambridge, MA: MIT Press).

Brander, J.A. and T.R. Lewis, 1986, Oligopoly and Financial Structure: The Limited Liability Effect, American Economic Review, 75: 956-970.

Brander, J. A., and M. Poitevin, 1992, Managerial Compensation and the Agency Costs of Debt Finance, Managerial and Decision Economics, 13: 55-64.

Breeden, D. and S. Viswanathan, 1998, Why Do Firms Hedge? An Asymmetric Information Model, Working Paper, Duke University.

Campbell, T. S., and W. A. Kracaw, 1987, Optimal Managerial Contracts and the Value of the Corporation, Journal of Financial and Quantitative Analysis, 22: 315-328.

Carter, D. A., D. A. Rogers, and B. J. Simkins, 2006, Does Hedging Affect Firm Value? Evidence from the US Airline Industry, Financial Management, 35: 53-86.

Chen, G., M. Firth, D. N. Gao, and O. M. Rui, 2006, Ownership Structure, Corporate Governance, and Fraud: Evidence from China, Journal of Corporate Finance, 12: 424-448.

Chen, G., M. Firth, Y. Xin, and L. Xu, 2008, Control Transfers, Privatization, and Corporate Performance: Efficiency Gains in China's Listed Companies, Journal of Financial and Quantitative Analysis, 43: $161-190$.

Coles, J. L., N. D. Daniel, and L. Naveen, 2008, Boards: Does One Size Fit All? Journal of Financial Economics, 87: 329-356.

Cull, R., and L. C. Xu, 2005, Institutions, Ownership, and Finance: The Determinants of Profit Reinvestment among Chinese Firms, Journal of Financial Economics, 77: 117-146.

DeMarzo, P., and D. Duffie, D., 1995, Corporate Incentives for Hedging and Hedge Accounting, Review of Financial Studies, 8: 743-772.

Dionne, G., and T. Triki, 2004, On Risk Management Determinants: What Does Really Work? Working Paper No. 04-04, HEC Montreal University.

Dionne, G., and T. Triki, 2005, Risk Management and Corporate Governance: the Importance of Independence and Financial Knowledge for the Board and the Audit Committee, Working Paper No. 05-03, HEC Montreal University.

Doherty, N. A., 2000, Integrated Risk Management: Techniques and Strategies For Reducing Risk (New York: McGraw-Hill). 
Fan, J. P. H., T. J. Wong, and T. Zhang, 2007, Politically Connected CEOs, Ccorporate Governance, and Post-IPO Performance of China's Newly Partially Privatized Firms, Journal of Financial Economics, 84: 330-357.

Fauver, L., and M. E. Fuerst, 2006, Does Good Corporate Governance Include Employee Representatives? Evidence from German Corporate Boards, Journal of Financial Economics, 82: 673-710.

Fisman, R., and J. Svensson, 2007, Are Corruption and Taxation Really Harmful to Growth? Firm Level Evidence, Journal of Development Economics, 83: 63-75.

Firth, M., C. Lin, P. Liu, and S. M. L. Wong, 2009, Inside the black box: Bank credit allocation in China's private sector, Journal of Banking and Finance, 33: 1144-1155.

Firth, M., P. M. Y. Fung, and O. M. Rui, 2006a, Corporate Performance and CEO Compensation in China, Journal of Corporate Finance, 12: 693-714.

Firth, M., P. M. Y. Fung, and O. M. Rui, 2006b, Firm Performance, Governance Structure, and Top Management Turnover in a Transitional Economy, Journal of Management Studies, 43: 1289-1330.

Garven, J. R., and R. D. MacMinn, 1993, The Underinvestment Problem, Bond Covenants and Insurance, Journal of Risk and Insurance, 60: 635-646.

Gompers, P., J. Ishi, and A. Metrick, 2003, Corporate Governance and Equity Prices, Quarterly Journal of Economics, 118: 107-155.

Graham, J. R., and D. A. Rogers, 2002, Do Firms Hedge in Response to Tax Incentives? Journal of Finance, 57: 815-839.

Han, L. M., 1996, Managerial Compensation and Corporate Demand for Insurance, Journal of Risk and Insurance, 63: 381-404.

Han, L. M., and R. D. MacMinn, 2006, Stock Options and the Corporate Demand for Insurance, Journal of Risk and Insurance, 73: 231-260.

Haushalter, D., S. Klasa, and W. F. Maxwell, 2007, The Influence of Product Market Dynamics on a Firm's Cash Holdings and Hedging Behavior, Journal of Financial Economics, 84: 797-825.

Holmstrom, B., and P. Milgrom, 1987, Aggregation and Linearity in Provision of Intertemporal Incentives, Econometrica, 55: 303-328.

Hoyt, R. E., and H. Khang, 2000, On the Demand for Corporate Property Insurance, Journal of Risk and Insurance, 67: 91-107.

Jaccard, J., R. Turrisi, and C. K. Wan, 1990, Interaction Effects in Multiple Regression, Sage University Paper Series on Quantitative Applications in the Social Sciences 07-069, Sage, Newbury Park, CA.

Kim, Y. S., J. Nam, and J. H. Thornton, 2008, The Effect of Managerial Bonus Plans on Corporate Derivatives Usage, Journal of Multinational Financial Management, 18: 229-243.

Lel, U., 2005, Currency Hedging and Corporate Governance: A Cross-country Analysis. Working Paper, Federal Reserve Board.

Lin, C., Y. Ma, and D. Su, 2008, Corporate Governance and Firm Efficiency: Evidence from China's Publicly Listed Firms, Managerial and Decision Economics, 30: 193-209.

Lin, C., P. Lin, and F. Song, 2009, Property Rights Protection and Corporate R\&D Activities: Evidence from China, Journal of Development Economics, 90, in press.

Liu, Q., and Z. Lu, 2007, Corporate Governance and Earnings Management in the Chinese Listed Companies: A Tunneling Perspective, Journal of Corporate Finance, 13: 881-906.

MacMinn, R. D., 1987, Insurance and Corporate Risk Management, Journal of Risk and Insurance, 55: 658-677.

MacMinn, R. D., 2005, The Fisher Model and Financial Markets (Singapore: World Scientific Publishing).

MacMinn, R. D., and L. M. Han, 1990, Limited Liability, Corporate Value, and the Demand for Liability Insurance, Journal of Risk and Insurance, 57: 581-607.

Marsden, A., and A. K. Prevost, 2005, Derivatives Use, Corporate Governance, and Legislative Change: An Empirical Analysis of New Zealand Listed Companies, Journal of Business Finance and Accounting, 32: 255-295.

May, D. O., 1995, Do Managerial Motives Influence Firm Risk Reduction Strategies? Journal of Finance, 50: 1291-1308.

Mayers, D., and C. W. Smith, 1982, On the Corporate Demand for Insurance, Journal of Business, 55: 281-296. 
Mayers, D., and C. W. Smith, 1987, Corporate Insurance and the Underinvestment Problem, Journal of Risk and Insurance, 54: 45-54.

Mayers, D., C. W. Smith, 1990, On the Corporate Demand for Insurance: Evidence from the Reinsurance Market, Journal of Business, 63: 19-40.

Petersen, M. A., and S. R. Thiagarajan, 2000, Measurement and Hedging: With and Without Derivatives, Financial Management, 29: 5-29.

Raheja, C. G., 2005, Determinants of Board Size and Composition: A Theory of Corporate Boards, Journal of Financial and Quantitative Analysis, 40: 283-306.

Regan, L., and Y, Hur, 2007, On the Corporate Demand for Insurance: The Case of Korean Nonfinancial Firms, Journal of Risk and Insurance, 74: 829-850.

Rogers, D., 2002, Does Executive Portfolio Structure Affect Risk Management? CEO Risk-Taking Incentives and Corporate Derivatives Use, Journal of Banking and Finance, 26: 271-295.

Ryan, H. E., and R. A. Wiggins, 2001, The Influence of Firm- and Manager-Specific Characteristics on the Structure of Executive Compensation, Journal of Corporate Finance, 7: 101-123.

Saunders, A., F. Strock, and N. Travlos, N., 1990, Ownership Structure, Deregulation, and Bank Risk Taking, Journal of Finance, 45: 643-654.

Seog, S. H., 2006, Strategic Demand for Insurance, Journal of Risk and Insurance, 73: 279-296.

Smith, C. W., and R. M. Stulz, 1985, The Determinants of Firms' Hedging Policies, Journal of Financial and Quantitative Analysis, 20: 391-404.

Sun, Q., and W. H. S. Tong, 2003, China Share Issue Privatization: The Extent of Its Success. Journal of Financial Economics, 70: 183-222.

Tenev, S., and C. Zhang, 2002, Corporate Governance and Enterprise Reform in China: Building the Institution of Modern Market (Washington, DC: World Bank and International Finance Corporation).

Tirole, J., 2001, Corporate Governance, Econometrica, 69: 1-35.

Tufano, P., 1996, Who Manages Risk? An Empirical Examination of Risk Management Practices in the Gold Mining Industry, Journal of Finance, 51: 1097-1137.

Wei, Z., F. Xie, and S. Zhang, 2005, Ownership Structure and Firm Value in China's Privatized Firms: 1991-2001, Journal of Financial and Quantitative Analysis, 40: 87-108.

World Bank 2004, Investment Climate Survey: China, (New York: World Bank).

Xiao, J. Z., J. Dahya, and Z. Lin, 2004, A Grounded Theory Exposition of the Role of the Supervisory Board in China, British Journal of Management, 15: 39-55.

Yamori, N., 1999, An Empirical Investigation of the Japanese Corporate Demand for Insurance, Journal of Risk and Insurance, 66: 239-252.

Zou, H., 2009, Hedging and Firm Value: Evidence from Property Insurance Use, Financial Management, in press.

Zou, H., and M. B. Adams, 2006, The Corporate Purchase of Property Insurance: Chinese Evidence, Journal of Financial Intermediation, 15: 165-196.

Zou, H., and M. B. Adams, 2008, Debt Capacity, Cost of Debt and Corporate Insurance, Journal of Financial and Quantitative Analysis, 43: 433-466.

Zou, H., M. B. Adams, and M. J. Buckle, 2003, Corporate Risks and Property Insurance: Evidence from the People's Republic of China, Journal of Risk and Insurance, 70: 289-314. 
Table 1 Variable Definitions

\begin{tabular}{|c|c|}
\hline Variable & Definition \\
\hline Insurance Dummy & $=1$ if the firm bought insurance in 2002 \\
\hline Insurance Intensity (\%) & $\begin{array}{l}\text { Property insurance premium /book value of tangible assets (fixed assets and } \\
\text { inventory) at the beginning of the year }\end{array}$ \\
\hline \multicolumn{2}{|l|}{ CEO Monitoring Variables } \\
\hline State-owned firms dummy & $=1$ if a firm's state (including collective) ownership $>50 \%$ \\
\hline Joint stock firms dummy & $=1$ if a firm is a publicly listed company or unlisted joint stock company \\
\hline $\begin{array}{l}\text { Foreign institutional } \\
\text { ownership }\end{array}$ & The faction of ownership held by foreign institutional investors \\
\hline Audit dummy & $=1$ if a firm's financial statements are audited by external auditors \\
\hline CEO-Chairman duality & $=1$ if the CEO and board chairman positions are held by a same person \\
\hline $\begin{array}{l}\text { Fraction of independent } \\
\text { directors }\end{array}$ & Number of independent directors on the board/ board size \\
\hline Board ownership & The fraction of board members holding company shares \\
\hline Bank collateral requirement & Dummy, 1 = if the bank requires collateral in the most recent loan decision \\
\hline Monitoring index & $\begin{array}{l}=\text { non-State-owned firms dummy + Joint stock companies dummy + dummy } \\
\text { for "foreign institutional ownership>sample median" + Audit dummy + } \\
\text { CEO-Chairman non-duality dummy + dummy for the existence of } \\
\text { independent directors on the board + dummy for "board ownership > } \\
\text { sample median" + dummy for the existence of a bank collateral } \\
\text { requirement. A higher value indicates stronger monitoring of CEOs. }\end{array}$ \\
\hline
\end{tabular}

CEO Incentives \& Characteristics

CEO cash compensation Natural logarithm of the times of CEO pay (salary + bonus) relative to the average pay of ordinary employees

Bonus plan dummy $\quad 1=$ CEO is rewarded by a bonus scheme relating to accounting profit

CEO stock ownership (\%) The percentage of a firm's shares held by the CEO

CEO tenure

CEO is a Party secretary

CEO's years in the current position

Dummy, = 1 if the CEO is a secretary of the Communist's Party

CEO was a manager

Dummy, = 1 if a manager was previously a CEO or deputy manager in another company before taking up the current position.

Safety evaluation dummy $\quad=1$ if a firm uses safety of operation as a performance evaluation criterion in incentive-based compensation

\section{Control Variables}

Firm size

Asset tangibility

Leverage (lagged)

Capx/Sales (lagged)

$R \& D /$ Sales (lagged)

Liquidity ratio (lagged)

Fraction of export

Natural log of book value of total assets (in thousand yuan)

(Average inventory + net book value of fixed assets)/total assets

Total debt ratio, lagged by one year

Average of capital expenditure in the previous two years (2000 and 2001) /average sales in 2000 and 2001

R\&D spending/total sales, lagged by one year

Current assets/current liabilities, lagged by one year

Average percentage of export sale to total sales over the previous three years (1999-2001)

Competition

Takes value 1-5, extracted from question A8 "In 2002 how many competitors do you have within your main business line in domestic market? (1) 1-3, (2) 4-6, (3)7-15, (4)16-100, (5) more than 100"

Board has an employee rep. Dummy, $1=$ there is at least employee representative on the board 
Table 2 Summary Statistics

\begin{tabular}{|c|c|c|c|c|c|c|c|}
\hline & \multicolumn{3}{|c|}{ Pooled $(n=1,081)$} & \multirow{2}{*}{$\begin{array}{l}\text { Users } \\
\text { mean }\end{array}$} & \multicolumn{3}{|l|}{ Non-users } \\
\hline & mean & median & $\mathrm{sd}$ & & Mean & $t$-stat $/ \chi^{2}$ & \\
\hline Insurance Dummy & 0.575 & 1.000 & 0.495 & & & & \\
\hline Insurance Intensity (\%) & 0.362 & 0.055 & 0.674 & 0.629 & 0.000 & & \\
\hline $\begin{array}{l}\text { Insurance Intensity (\%) in } \\
\text { insurance users }\end{array}$ & 0.629 & 0.279 & & & & & \\
\hline State-owned firms dummy & 0.224 & 0.000 & 0.417 & 0.247 & 0.194 & 7.490 & ${ }^{* * *}$ \\
\hline Joint stock firms dummy & 0.167 & 0.000 & 0.373 & 0.200 & 0.123 & 19.762 & ${ }^{* * *}$ \\
\hline Foreign institutional ownership & 0.015 & 0.000 & 0.106 & 0.022 & 0.006 & 3.590 & ${ }^{* * *}$ \\
\hline Audit dummy & 0.713 & 1.000 & 0.452 & 0.791 & 0.609 & 74.642 & ${ }^{* * *}$ \\
\hline CEO-Chairman duality & 0.243 & 0.000 & 0.429 & 0.244 & 0.243 & 0.007 & \\
\hline $\begin{array}{l}\text { Fraction of independent } \\
\text { directors }\end{array}$ & 0.070 & 0.000 & 0.183 & 0.083 & 0.053 & 3.594 & ${ }^{* * *}$ \\
\hline Board ownership (\%) & 24.564 & 0.000 & 39.307 & 26.012 & 22.608 & 1.867 & * \\
\hline Bank collateral requirement & 0.366 & 0.000 & 0.482 & 0.434 & 0.274 & 50.804 & *** \\
\hline CEO cash compensation & 1.609 & 1.386 & 1.259 & 1.808 & 1.340 & 8.335 & ${ }^{* * *}$ \\
\hline Bonus plan dummy & 0.219 & 0.000 & 0.413 & 0.247 & 0.180 & 12.084 & ${ }^{* * *}$ \\
\hline CEO stock ownership (\%) & 0.804 & 0.000 & 6.184 & 0.737 & 0.895 & -0.536 & \\
\hline CEO tenure & 5.927 & 5.000 & 4.379 & 5.960 & 5.883 & 0.386 & \\
\hline CEO is a Party secretary & 0.304 & 0.000 & 0.460 & 0.350 & 0.243 & 24.956 & ${ }^{* * *}$ \\
\hline CEO was a manager & 0.504 & 1.000 & 0.500 & 0.569 & 0.416 & 42.866 & ${ }^{* * *}$ \\
\hline Safety evaluation dummy & 0.048 & 0.000 & 0.215 & 0.056 & 0.038 & 3.578 & $*$ \\
\hline Firm size & 9.831 & 9.784 & 2.182 & 10.524 & 8.894 & 17.23 & ${ }^{* * *}$ \\
\hline Asset tangibility & 0.457 & 0.436 & 0.266 & 0.466 & 0.443 & 1.799 & * \\
\hline Leverage & 0.586 & 0.597 & 0.275 & 0.579 & 0.596 & -1.334 & \\
\hline Capx/Sales (lagged) & 0.074 & 0.022 & 0.121 & 0.083 & 0.062 & 3.710 & ${ }^{* * *}$ \\
\hline R\&D/Sales (lagged) & 0.007 & 0.000 & 0.021 & 0.009 & 0.004 & 4.505 & *** \\
\hline Liquidity ratio & 1.507 & 1.030 & 2.489 & 1.467 & 1.560 & -0.782 & \\
\hline Fraction of export & 0.080 & 0.000 & 0.243 & 0.102 & 0.051 & 4.670 & ${ }^{* * *}$ \\
\hline Competition & 3.798 & 4.000 & 1.358 & 3.681 & 3.956 & -4.397 & ${ }^{* * *}$ \\
\hline Board has an employee rep & 0.237 & 0.000 & 0.425 & 0.262 & 0.204 & 8.563 & $* * *$ \\
\hline Monitoring index (0-7) & 3.310 & 3.000 & 1.267 & 3.535 & 3.005 & 9.402 & $* * *$ \\
\hline
\end{tabular}

There are 1,081 insurance users and 800 non-users. The mean proportion of independent directors for the 391 firms with independent directors is 0.416 and the maximum is 1 . The comparison of means of continuous variables between users and non-users uses t-tests. $\chi^{2}$ test is used to test the independence between categorical firm characteristics and the incidence of insurance. $* * *, * *, *$ denote significance at the 1,5 , and 10 percent level, respectively (two-tailed). 
Table 3 Governance Monitoring, CEO Incentives and the Incidence \& the Extent of Property Insurance Use

\begin{tabular}{|c|c|c|c|c|}
\hline & $\frac{\text { Probit }}{(1)}$ & $\frac{\text { Tobit }}{(2)}$ & $\frac{\text { Probit }}{(3)}$ & $\frac{\text { Tobit }}{(4)}$ \\
\hline State-owned firms dummy & $\begin{array}{c}0.001 \\
{[0.992]}\end{array}$ & $\begin{array}{l}-0.011 \\
{[0.698]}\end{array}$ & & \\
\hline Joint stock firms dummy & $\begin{array}{c}0.039 \\
{[0.311]}\end{array}$ & $\begin{array}{c}0.033 \\
{[0.401]}\end{array}$ & & \\
\hline Foreign institutional ownership & $\begin{array}{l}0.258^{*} \\
{[0.064]}\end{array}$ & $\begin{array}{c}0.008 \\
{[0.885]}\end{array}$ & & \\
\hline Audit dummy & $\begin{array}{c}0.101^{* * *} \\
{[0.002]}\end{array}$ & $\begin{array}{c}0.079 * * \\
{[0.012]}\end{array}$ & & \\
\hline CEO-Chairman duality & $\begin{array}{c}-0.055^{* *} \\
{[0.014]}\end{array}$ & $\begin{array}{l}-0.045^{*} \\
{[0.059]}\end{array}$ & & \\
\hline $\begin{array}{l}\text { Proportion of independent } \\
\text { directors }\end{array}$ & $\begin{array}{c}0.054 \\
{[0.440]}\end{array}$ & $\begin{array}{l}-0.003 \\
{[0.954]}\end{array}$ & & \\
\hline Board ownership & $\begin{array}{l}0.001^{*} \\
{[0.060]}\end{array}$ & $\begin{array}{c}0.001 \\
{[0.373]}\end{array}$ & & \\
\hline Bank collateral requirement & $\begin{array}{c}0.030 \\
{[0.382]}\end{array}$ & $\begin{array}{c}0.013 \\
{[0.625]}\end{array}$ & & \\
\hline Monitoring index & & & $\begin{array}{c}0.042^{* * *} \\
{[0.000]}\end{array}$ & $\begin{array}{c}0.025^{* *} \\
{[0.023]}\end{array}$ \\
\hline CEO cash compensation & $\begin{array}{l}0.021^{* *} \\
{[0.043]}\end{array}$ & $\begin{array}{c}0.013 \\
{[0.251]}\end{array}$ & $\begin{array}{l}0.018^{*} \\
{[0.075]}\end{array}$ & $\begin{array}{c}0.011 \\
{[0.335]}\end{array}$ \\
\hline Bonus plan dummy & $\begin{array}{c}0.004 \\
{[0.876]}\end{array}$ & $\begin{array}{l}-0.015 \\
{[0.457]}\end{array}$ & $\begin{array}{c}0.002 \\
{[0.935]}\end{array}$ & $\begin{array}{l}-0.013 \\
{[0.508]}\end{array}$ \\
\hline CEO stock ownership (\%) & $\begin{array}{c}-0.001 \\
{[0.667]}\end{array}$ & $\begin{array}{c}-0.001 \\
{[0.790]}\end{array}$ & $\begin{array}{l}-0.001 \\
{[0.665]}\end{array}$ & $\begin{array}{l}-0.001 \\
{[0.774]}\end{array}$ \\
\hline CEO tenure & $\begin{array}{l}0.006^{*} \\
{[0.056]}\end{array}$ & $\begin{array}{c}0.002 \\
{[0.606]}\end{array}$ & $\begin{array}{l}0.006^{*} \\
{[0.071]}\end{array}$ & $\begin{array}{c}0.002 \\
{[0.644]}\end{array}$ \\
\hline CEO is a Party secretary & $\begin{array}{c}0.077^{* * *} \\
{[0.004]}\end{array}$ & $\begin{array}{c}0.041 \\
{[0.299]}\end{array}$ & $\begin{array}{c}0.081 * * * \\
{[0.002]}\end{array}$ & $\begin{array}{c}0.044 \\
{[0.273]}\end{array}$ \\
\hline CEO was a manager & $\begin{array}{c}0.053^{* *} \\
{[0.045]}\end{array}$ & $\begin{array}{c}0.039 \\
{[0.166]}\end{array}$ & $\begin{array}{c}0.056^{* *} \\
{[0.027]}\end{array}$ & $\begin{array}{c}0.042 \\
{[0.132]}\end{array}$ \\
\hline Safety evaluation dummy & $\begin{array}{l}-0.012 \\
{[0.884]}\end{array}$ & $\begin{array}{l}0.128^{*} \\
{[0.100]}\end{array}$ & $\begin{array}{l}-0.007 \\
{[0.935]}\end{array}$ & $\begin{array}{l}0.133^{*} \\
{[0.090]}\end{array}$ \\
\hline Firm size & $\begin{array}{c}0.061^{* * *} \\
{[0.000]}\end{array}$ & $\begin{array}{c}0.016 \\
{[0.149]}\end{array}$ & $\begin{array}{c}0.066^{* * *} \\
{[0.000]}\end{array}$ & $\begin{array}{l}0.019^{*} \\
{[0.061]}\end{array}$ \\
\hline Asset tangibility & $\begin{array}{c}0.114^{* * *} \\
{[0.000]}\end{array}$ & $\begin{array}{c}-0.167^{* * *} \\
{[0.000]}\end{array}$ & $\begin{array}{c}0.118^{* * *} \\
{[0.000]}\end{array}$ & $\begin{array}{c}-0.165^{* * *} \\
{[0.000]}\end{array}$ \\
\hline Leverage (lagged) & $\begin{array}{l}-0.044 \\
{[0.381]}\end{array}$ & $\begin{array}{c}0.021 \\
{[0.662]}\end{array}$ & $\begin{array}{l}-0.051 \\
{[0.314]}\end{array}$ & $\begin{array}{c}0.018 \\
{[0.708]}\end{array}$ \\
\hline Asset tangibility $\times$ Leverage & $\begin{array}{c}0.230 \\
{[0.189]}\end{array}$ & $\begin{array}{l}0.324^{*} \\
{[0.058]}\end{array}$ & $\begin{array}{c}0.231 \\
{[0.179]}\end{array}$ & $\begin{array}{l}0.320^{*} \\
{[0.063]}\end{array}$ \\
\hline Capx/Sales (lagged) & $\begin{array}{c}0.071 \\
{[0.392]}\end{array}$ & $\begin{array}{c}-0.109 \\
{[0.140]}\end{array}$ & $\begin{array}{c}0.072 \\
{[0.389]}\end{array}$ & $\begin{array}{l}-0.112 \\
{[0.136]}\end{array}$ \\
\hline R\&D/Sales (lagged) & $\begin{array}{c}1.118 \\
{[0.196]}\end{array}$ & $\begin{array}{c}0.632 \\
{[0.253]}\end{array}$ & $\begin{array}{c}1.061 \\
{[0.219]}\end{array}$ & $\begin{array}{c}0.588 \\
{[0.275]}\end{array}$ \\
\hline
\end{tabular}




\begin{tabular}{lcccc}
\hline Leverage $\times$ Capx/Sales & -0.615 & -0.487 & -0.560 & -0.488 \\
& {$[0.133]$} & {$[0.129]$} & {$[0.142]$} & {$[0.105]$} \\
Leverage $\times$ R\&D/Sales & 2.253 & $2.589^{* *}$ & 2.205 & $2.472^{* *}$ \\
& {$[0.252]$} & {$[0.020]$} & {$[0.259]$} & {$[0.033]$} \\
Liquidity ratio (lagged) & 0.001 & $0.012^{* * *}$ & 0.001 & $0.012^{* * *}$ \\
& {$[0.817]$} & {$[0.003]$} & {$[0.918]$} & {$[0.005]$} \\
Fraction of export & 0.080 & $0.119^{*}$ & 0.090 & $0.124^{*}$ \\
& {$[0.189]$} & {$[0.057]$} & {$[0.153]$} & {$[0.058]$} \\
Competition & 0.006 & 0.008 & 0.005 & 0.007 \\
& {$[0.562]$} & {$[0.527]$} & {$[0.602]$} & {$[0.553]$} \\
Board has an employee rep. & 0.010 & $0.058^{* *}$ & -0.004 & 0.044 \\
& {$[0.718]$} & {$[0.043]$} & {$[0.897]$} & {$[0.151]$} \\
Industry dummies & Yes & Yes & Yes & Yes \\
City dummies & Yes & Yes & Yes & Yes \\
Log pseudolikelihood & -1058.1 & -1996.5 & -1062.6 & -1999.0 \\
$\mathrm{~N}$ & 1881 & 1881 & 1881 & 1881 \\
Left-censored observations & & 800 & & 800 \\
\hline
\end{tabular}

The table reports the results from the Probit model (where the dependent variable is the Insurance Dummy) and the Tobit regression (left censored at zero) (where the dependent variable is Insurance Intensity). Marginal effects are reported. Reported in parentheses are $p$-value computed using heteroskedasticity robust standard errors clustered at the city level to allow for cross-sectional correlation. $* * *, * *, *$ denote significance at the 1,5 , and 10 percent level, respectively (two-tailed). The intercept is included in all models but its coefficient is unreported for brevity. Marginal effects for discrete dummy variables are computed for the change from 0 to 1 . Marginal effects for continuous variables are evaluated at sample means. 
Table 4: Split Sample Analysis by Monitoring Index

\begin{tabular}{|c|c|c|c|c|}
\hline & Probit & & Tobit & \\
\hline & $\begin{array}{c}\text { Monitoring } \\
\text { index }>\text { median }\end{array}$ & $\begin{array}{c}\text { Monitoring } \\
\text { index<=median }\end{array}$ & $\begin{array}{c}\text { Monitoring } \\
\text { index }>\text { median }\end{array}$ & $\begin{array}{c}\text { Monitoring } \\
\text { index }<=\text { median }\end{array}$ \\
\hline CEO cash compensation & $\begin{array}{l}-0.005 \\
{[0.643]}\end{array}$ & $\begin{array}{c}0.036 * * \\
{[0.024]}\end{array}$ & $\begin{array}{c}0.013 \\
{[0.458]}\end{array}$ & $\begin{array}{c}0.013 \\
{[0.467]}\end{array}$ \\
\hline Bonus plan dummy & $\begin{array}{l}-0.051 \\
{[0.112]}\end{array}$ & $\begin{array}{c}0.034 \\
{[0.351]}\end{array}$ & $\begin{array}{l}-0.018 \\
{[0.547]}\end{array}$ & $\begin{array}{l}-0.019 \\
{[0.524]}\end{array}$ \\
\hline CEO stock ownership (\%) & $\begin{array}{c}0.005 \\
{[0.108]}\end{array}$ & $\begin{array}{l}-0.002 \\
{[0.451]}\end{array}$ & $\begin{array}{c}0.003 \\
{[0.513]}\end{array}$ & $\begin{array}{l}-0.003 \\
{[0.404]}\end{array}$ \\
\hline CEO tenure & $\begin{array}{c}0.001 \\
{[0.854]}\end{array}$ & $\begin{array}{c}0.007^{* *} \\
{[0.037]}\end{array}$ & $\begin{array}{c}-0.008 * * \\
{[0.030]}\end{array}$ & $\begin{array}{l}0.007^{*} \\
{[0.063]}\end{array}$ \\
\hline CEO is a Party secretary & $\begin{array}{l}-0.022 \\
{[0.601]}\end{array}$ & $\begin{array}{c}0.121 * * * \\
{[0.001]}\end{array}$ & $\begin{array}{c}0.018 \\
{[0.708]}\end{array}$ & $\begin{array}{c}0.056 \\
{[0.219]}\end{array}$ \\
\hline CEO was a manager & $\begin{array}{c}0.025 \\
{[0.494]}\end{array}$ & $\begin{array}{c}0.091 * * * \\
{[0.003]}\end{array}$ & $\begin{array}{l}-0.018 \\
{[0.710]}\end{array}$ & $\begin{array}{c}0.083 * * * \\
{[0.001]}\end{array}$ \\
\hline Safety evaluation dummy & $\begin{array}{l}-0.115 \\
{[0.370]}\end{array}$ & $\begin{array}{c}0.094 \\
{[0.151]}\end{array}$ & $\begin{array}{l}-0.038 \\
{[0.729]}\end{array}$ & $\begin{array}{c}0.284 * * * \\
{[0.003]}\end{array}$ \\
\hline Firm size & $\begin{array}{c}0.081 * * * \\
{[0.000]}\end{array}$ & $\begin{array}{c}0.055 * * * \\
{[0.000]}\end{array}$ & $\begin{array}{c}0.018 \\
{[0.219]}\end{array}$ & $\begin{array}{l}0.018^{*} \\
{[0.093]}\end{array}$ \\
\hline Asset tangibility & $\begin{array}{c}0.002 \\
{[0.978]}\end{array}$ & $\begin{array}{c}0.155^{* *} \\
{[0.013]}\end{array}$ & $\begin{array}{c}-0.294 * * * \\
{[0.000]}\end{array}$ & $\begin{array}{l}-0.094 \\
{[0.212]}\end{array}$ \\
\hline Leverage (lagged) & $\begin{array}{l}-0.079 \\
{[0.346]}\end{array}$ & $\begin{array}{c}0.010 \\
{[0.868]}\end{array}$ & $\begin{array}{c}0.098 \\
{[0.408]}\end{array}$ & $\begin{array}{c}0.012 \\
{[0.811]}\end{array}$ \\
\hline Asset tangibility $\times$ Leverage & $\begin{array}{c}0.236 \\
{[0.325]}\end{array}$ & $\begin{array}{c}0.151 \\
{[0.426]}\end{array}$ & $\begin{array}{c}0.201 \\
{[0.544]}\end{array}$ & $\begin{array}{l}0.286^{*} \\
{[0.089]}\end{array}$ \\
\hline Capx/Sales (lagged) & $\begin{array}{l}0.356^{*} \\
{[0.090]}\end{array}$ & $\begin{array}{l}-0.048 \\
{[0.708]}\end{array}$ & $\begin{array}{c}-0.072 \\
{[0.716]}\end{array}$ & $\begin{array}{l}-0.127 \\
{[0.280]}\end{array}$ \\
\hline R\&D/Sales (lagged) & $\begin{array}{c}1.014 \\
{[0.260]}\end{array}$ & $\begin{array}{c}1.077 \\
{[0.340]}\end{array}$ & $\begin{array}{l}1.169^{*} \\
{[0.069]}\end{array}$ & $\begin{array}{c}0.328 \\
{[0.709]}\end{array}$ \\
\hline Leverage $\times$ Capx/Sales & $\begin{array}{c}0.535 \\
{[0.326]}\end{array}$ & $\begin{array}{c}-0.711 \\
{[0.227]}\end{array}$ & $\begin{array}{c}0.171 \\
{[0.743]}\end{array}$ & $\begin{array}{c}-0.656 \\
{[0.160]}\end{array}$ \\
\hline Leverage $\times R \& D /$ Sales & $\begin{array}{l}-1.312 \\
{[0.504]}\end{array}$ & $\begin{array}{c}5.928 \\
{[0.102]}\end{array}$ & $\begin{array}{c}0.606 \\
{[0.756]}\end{array}$ & $\begin{array}{c}3.153 \\
{[0.184]}\end{array}$ \\
\hline Liquidity ratio (lagged) & $\begin{array}{c}-0.016^{* *} \\
{[0.038]}\end{array}$ & $\begin{array}{c}0.008 \\
{[0.219]}\end{array}$ & $\begin{array}{c}0.001 \\
{[0.921]}\end{array}$ & $\begin{array}{c}0.018^{* * *} \\
{[0.005]}\end{array}$ \\
\hline Fraction of export & $\begin{array}{c}0.027 \\
{[0.704]}\end{array}$ & $\begin{array}{c}0.160 \\
{[0.105]}\end{array}$ & $\begin{array}{c}0.079 \\
{[0.247]}\end{array}$ & $\begin{array}{l}0.193^{*} \\
{[0.078]}\end{array}$ \\
\hline Competition & $\begin{array}{c}0.034 * * * \\
{[0.010]}\end{array}$ & $\begin{array}{l}-0.011 \\
{[0.418]}\end{array}$ & $\begin{array}{c}0.016 \\
{[0.330]}\end{array}$ & $\begin{array}{c}0.003 \\
{[0.849]}\end{array}$ \\
\hline Board has an employee rep. & $\begin{array}{c}0.014 \\
{[0.769]}\end{array}$ & $\begin{array}{l}-0.035 \\
{[0.474]}\end{array}$ & $\begin{array}{c}0.049 \\
{[0.379]}\end{array}$ & $\begin{array}{c}0.039 \\
{[0.398]}\end{array}$ \\
\hline Industry dummies & Yes & Yes & Yes & Yes \\
\hline City dummies & Yes & Yes & Yes & Yes \\
\hline Log pseudolikelihood & -333.27 & -693.68 & -741.66 & -1212.70 \\
\hline $\mathrm{N}$ & 709 & 1172 & 709 & 1172 \\
\hline Left-censored observations & & & 208 & 592 \\
\hline
\end{tabular}

The table reports the results from the Probit and Tobit models based on two sub-samples categorized by whether the monitoring index is above the sample median or not. Marginal effects are reported. Reported in parentheses are $p$-value computed using heteroskedasticity robust standard errors clustered at the city level to allow for cross-sectional correlation. $* * *, * * *$ denote significance at the 1,5 , and 10 percent level, respectively (two-tailed). The intercept is included in all models but its coefficient is unreported for brevity. 
Table 5: Tobit Results from Using Instrumented CEO Compensation Variables

\begin{tabular}{|c|c|c|c|c|}
\hline & (1) & (2) & (3) & (4) \\
\hline & Pooled & Pooled & $\begin{array}{c}\text { Monitoring } \\
\text { index }>\text { median }\end{array}$ & $\begin{array}{c}\text { Monitoring } \\
\text { index }<=\text { median }\end{array}$ \\
\hline \multirow[t]{2}{*}{ State-owned firms dummy } & -0.006 & & & \\
\hline & {$[0.826]$} & & & \\
\hline \multirow[t]{2}{*}{ Joint stock firms dummy } & 0.035 & & & \\
\hline & {$[0.367]$} & & & \\
\hline \multirow[t]{2}{*}{ Foreign institutional ownership } & 0.013 & & & \\
\hline & {$[0.811]$} & & & \\
\hline \multirow[t]{2}{*}{ Audit dummy } & $0.078 * *$ & & & \\
\hline & {$[0.014]$} & & & \\
\hline \multirow[t]{2}{*}{ CEO-Chairman duality } & $-0.048 * *$ & & & \\
\hline & {$[0.037]$} & & & \\
\hline \multicolumn{5}{|l|}{ Proportion of independent } \\
\hline \multirow[t]{2}{*}{ directors } & -0.009 & & & \\
\hline & [0.873] & & & \\
\hline \multirow[t]{2}{*}{ Board ownership } & 0.001 & & & \\
\hline & {$[0.364]$} & & & \\
\hline \multirow[t]{2}{*}{ Bank collateral requirement } & 0.010 & & & \\
\hline & [0.689] & & & \\
\hline \multirow[t]{2}{*}{ CEO cash compensation (iv) } & $0.028 * *$ & $0.025^{*}$ & 0.016 & $0.038^{*}$ \\
\hline & {$[0.047]$} & {$[0.076]$} & [0.451] & {$[0.052]$} \\
\hline \multirow[t]{2}{*}{ CEO stock ownership (\%)(iv) } & 0.001 & 0.001 & 0.003 & -0.002 \\
\hline & {$[0.970]$} & [0.991] & [0.467] & {$[0.742]$} \\
\hline \multirow[t]{2}{*}{ Bonus plan dummy (iv) } & -0.033 & -0.032 & -0.030 & -0.046 \\
\hline & {$[0.380]$} & {$[0.363]$} & [0.628] & {$[0.221]$} \\
\hline \multirow[t]{2}{*}{ CEO tenure } & 0.002 & 0.001 & $-0.008 * *$ & $0.006^{*}$ \\
\hline & [0.628] & {$[0.674]$} & [0.028] & {$[0.077]$} \\
\hline \multirow[t]{2}{*}{ CEO is a Party secretary } & 0.042 & 0.046 & 0.018 & 0.061 \\
\hline & {$[0.286]$} & {$[0.262]$} & [0.710] & [0.196] \\
\hline \multirow[t]{2}{*}{ CEO was a manager } & 0.039 & 0.043 & -0.018 & $0.085^{* * *}$ \\
\hline & {$[0.152]$} & {$[0.115]$} & [0.712] & {$[0.001]$} \\
\hline \multirow[t]{2}{*}{ Safety evaluation dummy } & $0.133^{*}$ & $0.140^{*}$ & -0.037 & $0.294 * * *$ \\
\hline & [0.095] & {$[0.082]$} & {$[0.736]$} & {$[0.001]$} \\
\hline \multirow[t]{2}{*}{ Firm size } & 0.015 & $0.018^{*}$ & 0.018 & 0.016 \\
\hline & {$[0.185]$} & {$[0.075]$} & [0.217] & [0.144] \\
\hline \multirow[t]{2}{*}{ Asset tangibility } & $-0.170 * * *$ & $-0.168 * * *$ & $-0.294 * * *$ & -0.100 \\
\hline & {$[0.000]$} & {$[0.000]$} & {$[0.000]$} & {$[0.184]$} \\
\hline \multirow[t]{2}{*}{ Leverage (lagged) } & 0.024 & 0.022 & 0.098 & 0.021 \\
\hline & [0.598] & {$[0.655]$} & [0.404] & {$[0.655]$} \\
\hline \multirow[t]{2}{*}{ Asset tangibility $\times$ Leverage } & $0.318^{*}$ & $0.315^{*}$ & 0.203 & 0.280 \\
\hline & {$[0.061]$} & {$[0.066]$} & [0.548] & {$[0.105]$} \\
\hline \multirow[t]{2}{*}{ Capx/Sales (lagged) } & -0.102 & -0.106 & -0.072 & -0.123 \\
\hline & {$[0.183]$} & {$[0.176]$} & {$[0.718]$} & {$[0.313]$} \\
\hline
\end{tabular}




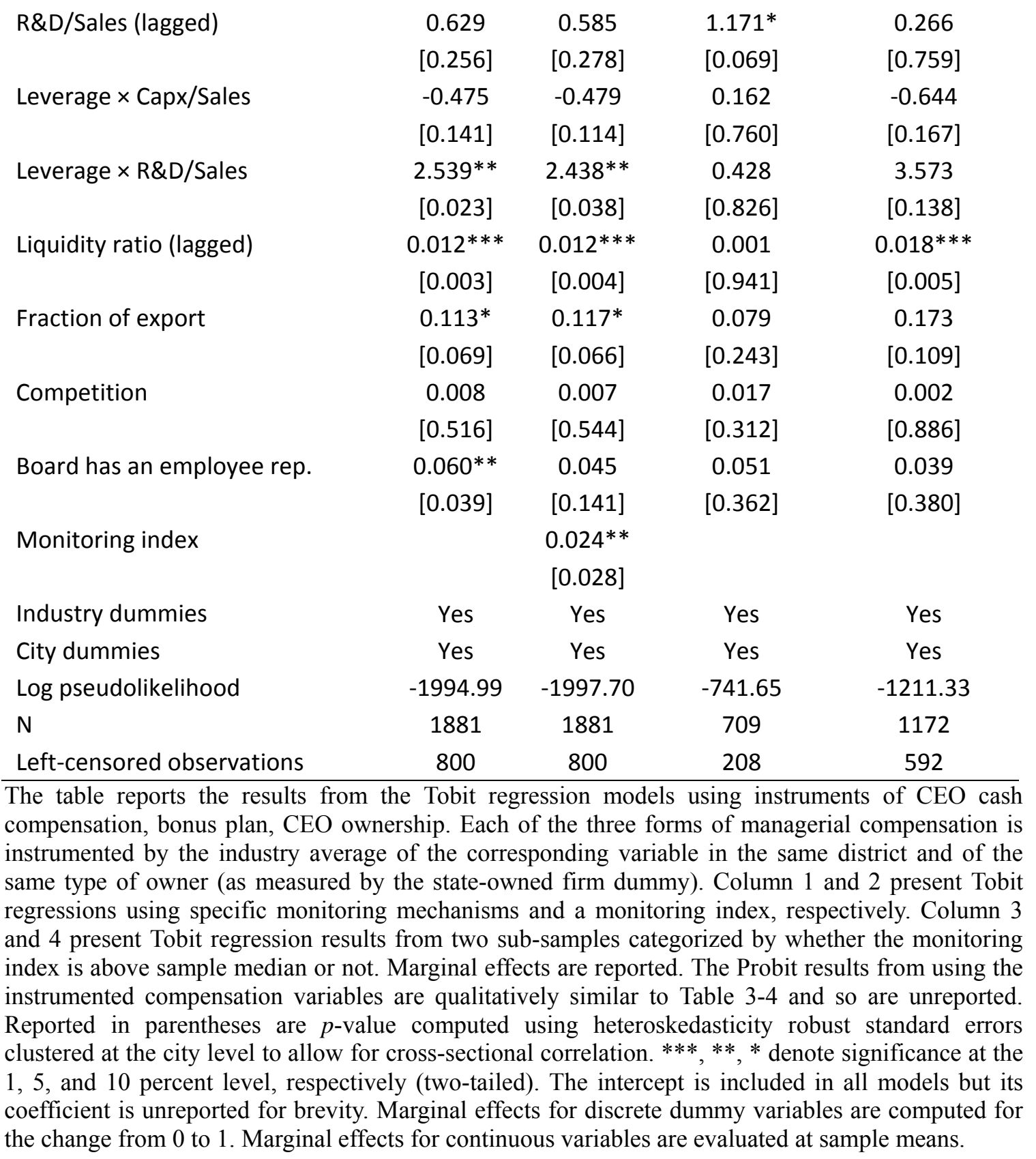

